\title{
The Behavior of Non-Oil Commodity Prices
}

Eduardo Borensztein, Mohsin S. Khan, Carmen M. Reinhart, and Peter Wickham

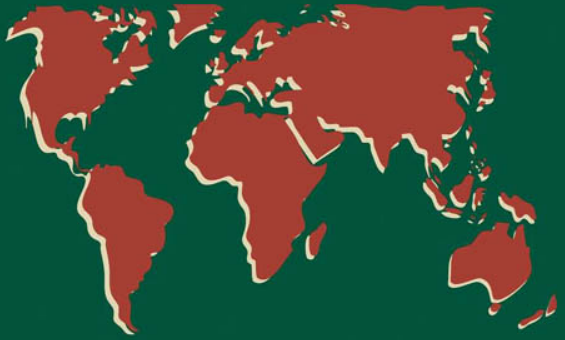




\section{The Behavior of Non-Oil Commodity Prices}

Eduardo Borensztein, Mohsin S. Khan, Carmen M. Reinhart, and Peter Wickham 
(C) 1994 International Monetary Fund

\section{Library of Congress Cataloging-in-Publication Data}

The behavior of non-oil commodity prices / Eduardo Borensztein ... [et al.].

p. cm. - (Occasional Papers, ISSN 0251-6365; 112)

Includes bibliographical references.

ISBN 1-55775-412-8

1. Prices. 2. Prices - Government policy. I. Borensztein, Eduardo. II. Series: Occasional paper (International Monetary Fund) ; no. 112. HB231.B44 1994

$338.5 \cdot 2-\mathrm{dc} 20$

94-33965

Price: US\$15.00

(US $\$ 12.00$ to full-time faculty members and students at universities and colleges)

Please send orders to:

International Monetary Fund, Publication Services 700 19th Street, N.W., Washington, D.C. 20431, U.S.A.

Tel.: (202) 623-7430 Telefax: (202) 623-7201

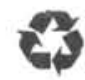

recycled paper 


\section{Contents}

Preface vii

I. Introduction I

II. Characteristics of Commodity Price Behavior 6

Trends and Cycles in Commodity Prices

Size of the Permanent Component of Price Shocks

Increasing Volatility of Commodity Prices $\frac{6}{7}$

ancreasing Volatility of Commodity Prices

III. Determinants of Commodity Price Movements 10

$\begin{array}{ll}\text { Economic Growth and the Demand for Commodities } & 10\end{array}$

Expansion in Supply

International Commodity Agreements 12

\begin{tabular}{ll}
\hline Developments in Economies in Transition & 14 \\
\hline
\end{tabular}

Econometric Model Results 16

\begin{tabular}{lr} 
IV. Policy Issues & 17 \\
\hline
\end{tabular}

\begin{tabular}{ll} 
Temporary Price Shocks & 17 \\
\hline Rof & 17
\end{tabular}

\begin{tabular}{ll} 
Role of Government in Smoothing Income & 17 \\
\hline Intervention Strategies & 18
\end{tabular}

\begin{tabular}{lr} 
Intervention Strategies & 18 \\
\hline Stabilization Funds & 19
\end{tabular}

$\begin{array}{ll}\text { Agricultural Boards } & 19\end{array}$

International Commodity Agreements 21

External Compensatory Finance 21

\begin{tabular}{ll} 
Market-Related Instruments & 21 \\
\hline
\end{tabular}

Government Policies for the Longer Term 22

V. Conclusion

25

\section{Tables}

\section{Section}

I. 1. Structure of Merchandise Exports:

\begin{tabular}{ll} 
Selected Developing Countries, 1965 and 1990 & 3 \\
\hline eal Export Earnings, 1970-92
\end{tabular}

II. 3. Share of the Variance of Changes in Real Non-Oil

Commodity Prices Due to Permanent Shocks, 1957-92

III. 4. Intensity of Metals Use in Major Industrial Countries 
5. Demand for Selected Commodities of the Former Soviet Union

6. Supply of Selected Commodities from the Former Soviet Union

\section{Charts}

\section{Section}

I. 1. Real Non-Oil Commodity Prices: Long-Term Developments, 1900-92

2. Volume and Real Value of Non-Oil Commodity Exports

3. Export Volumes by Region and Commodity Grouping

II. 4. Real Non-Oil Commodity Prices: Trends and Cycles, 1962:I-1993:II

5. Rising Volatility in Real Non-Oil Commodity Prices, 1972:I-1993:II

\begin{tabular}{ll} 
III. & . Factors Affecting Commodity Markets \\
\hline
\end{tabular}

\begin{tabular}{ll} 
7. Cereal Yields by Region & 14 \\
\hline
\end{tabular}

8. Real Non-Oil Commodity Prices: Actual and Forecasts

16

\section{Appendix}

Tables

A1. Country Groupings for Charts 2 and 3

A2. Country Groupings for Chart 7

The following symbols have been used throughout this paper:

... to indicate that data are not available;

- to indicate that the figure is zero or less than half the final digit shown, or that the item does not exist;

- between years or months (e.g., 1991-92 or January-June) to indicate the years or months covered, including the beginning and ending years or months;

I between years (e.g., 1991/92) to indicate a crop or fiscal (financial) year.

"Billion" means a thousand million.

Minor discrepancies between constituent figures and totals are due to rounding.

The term "country," as used in this paper, does not in all cases refer to a territorial entity that is a state as understood by international law and practice; the term also covers some territorial entities that are not states, but for which statistical data are maintained and provided internationally on a separate and independent basis. 


\section{Preface}

This paper is based on a study carried out in late 1993 in the Research Department of the Fund. The authors received useful comments from staff in other departments. The authors wish to thank Ximena Cheetham, Brian Casabianca, and Jared Romey for research assistance and Maria Orihuela and Elizabeth Whitely for secretarial assistance. Thanks are also due to Simon Willson of the External Relations Department who edited the manuscript and coordinated the publication process.

The opinions expressed in the paper are those of the authors and do not necessarily reflect the views of the IMF or its Executive Directors. 
This page intentionally left blank

CInternational Monetary Fund. Not for Redistribution 


\section{Introduction}

T he need to understand the factors that influence the behavior of commodity prices has taken on a special urgency in recent years, as nonoil real commodity prices have been declining almost continuously since the early 1980s. Since their short-lived recovery in 1984, real non-oil commodity prices have fallen by about 45 percent, translating into a sharp deterioration in the terms of trade for most commodity-dependent exporters. As Chart 1 illustrates, in 1992 the price of non-oil commodities relative to that of manufactures reached its lowest level in over 90 years. ${ }^{1}$ The longterm behavior of real commodity prices would thus appear to lend some support to the well-known Prebisch-Singer hypothesis. ${ }^{2}$ This pattern in commodity prices has important practical implications for policymakers. For example, the presence of a negative trend in commodity prices implies continuously worsening terms of trade for many commodity-dependent countries, and further that efforts to stabilize the incomes of producers for an extended period of time may not be financially sustainable.

While the decline in prices has affected all commodity-producing countries in some measure, for some countries the growth in the volume of exports has been of such magnitude that they have not experienced a decline in total real earnings from commodity exports. As can be seen from Chart 2, industrial countries and Asian countries have achieved sustained increases in the real value of their commodity export earnings. Latin American countries have generally maintained the real

\footnotetext{
${ }^{1}$ The source of the data plotted in Chart 1 is Grilli and Yang (1988) for the period $1900-86$ and updated by Reinhart and Wickham (1994) for 1987-92. Throughout this paper, references to commodity prices and exports exclude energy products.

${ }^{2}$ Basically, the Prebisch-Singer hypothesis posits that the long-term trend of the price of primary commodities relative to the price of manufactures is negative-see Prebisch (1950) and Singer (1950). Empirical evidence for the Prebisch-Singer hypothesis is, however, not conclusive (see, for example, Sapsford (1985), Cuddington and Urzua (1989), and Ardeni and Wright (1992)).
}

\section{Chart I. Real Non-Oil Commodity Prices: Long-Term Developments, 1900-92}
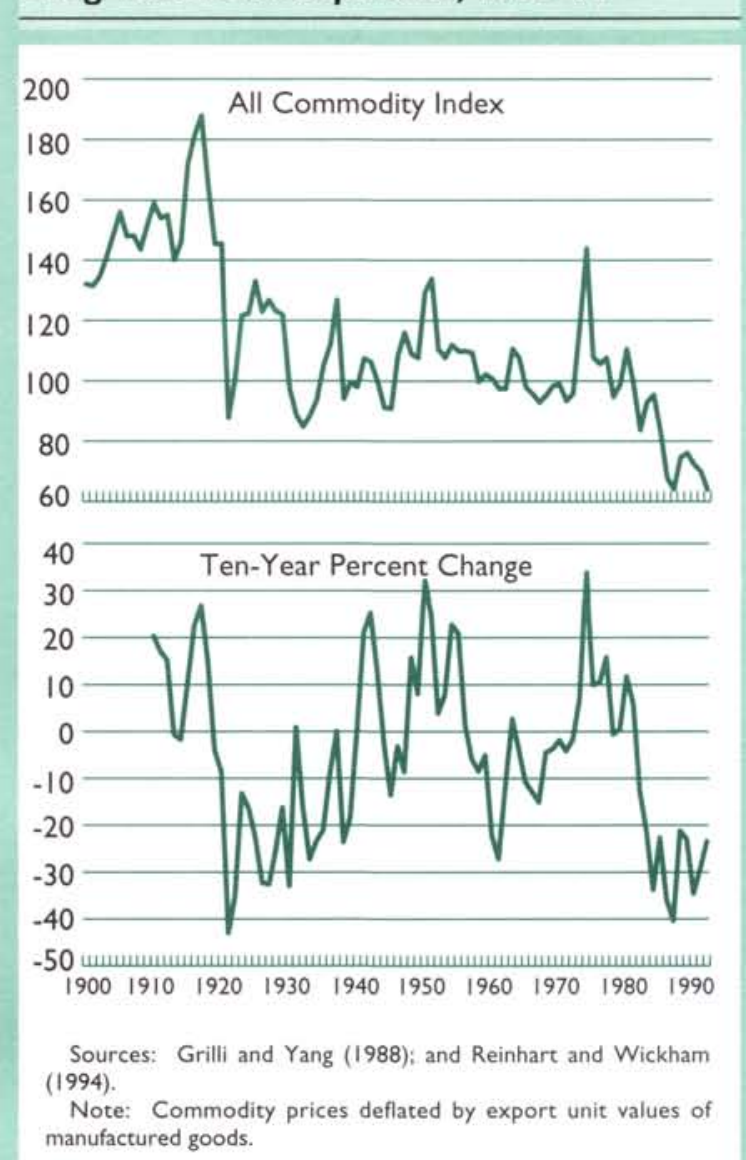

value of their commodity exports, while for the group of African countries the commodity price decline of the last decade has caused a sharp decrease in the real value of exports, as the volume of their exports has declined as well. As shown in Chart 3, the regional pattern of the evolution of 


\section{Chart 2. Volume and Real Value of Non-Oil Commodity Exports}

(Index Numbers: $1970=100$ )
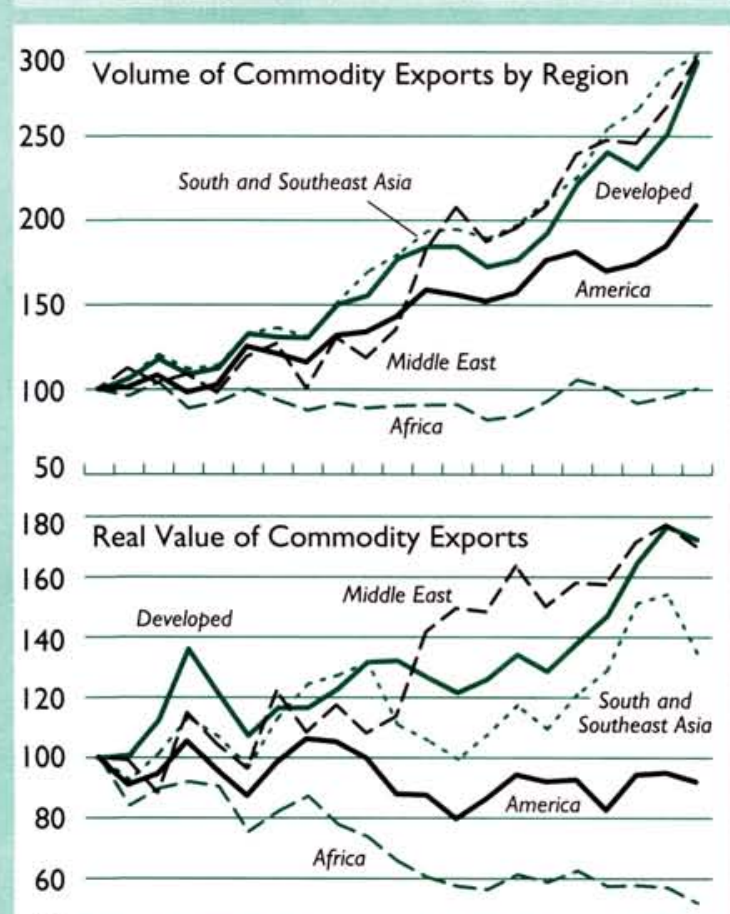

40

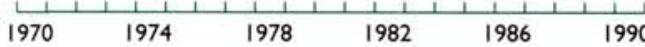

Source: United Nations Conference on Trade and Development, Handbook of International Trade and Development Statistics, 1992 (Geneva: UNCTAD, 1993).

Note: For country groupings see Table Al.

commodity exports is suggestive of similarities across commodity groups. ${ }^{3}$

It is to be expected that the decline in commodity prices will have its largest impact on countries with the least diversified production structure. Primary commodities still account for the bulk of exports in many developing countries. Moreover, this group of countries, which encompasses many of the lowest-income countries in the world, tends to have less flexible economic systems, making substitution away from commodity production more difficult or costly. In effect, the reliance on primary commodities as the main source of export earnings

${ }^{3}$ Note that the huge percentage increase in exports of minerals and metals by the group of Middle Eastern countries arguably did not have a major impact on markets since they represent a very small fraction of supply, namely, less than 2 percent by the end of 1990 .

\section{Chart 3. Export Volumes by Region and Commodity Grouping}

(Index numbers: $1970=100$ )
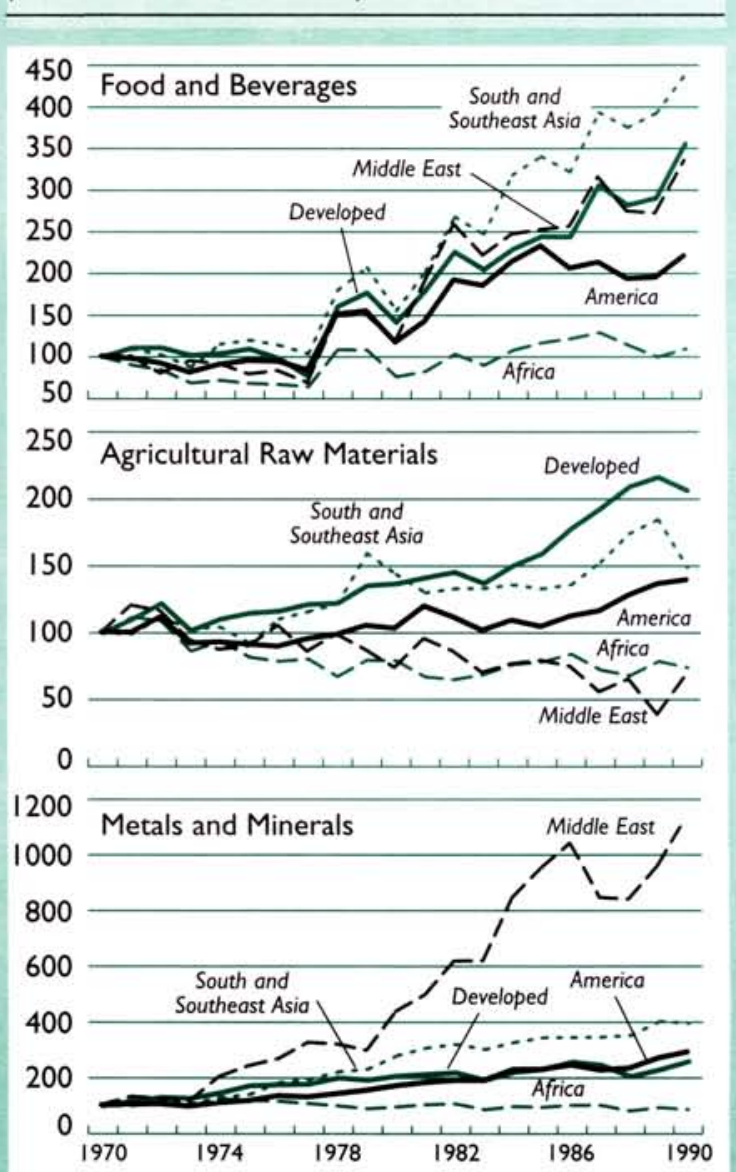

Source: UNCTAD, Handbook of International Trade and Development Statistics, 1992 (Geneva: UNCTAD, 1993). Note: For country groupings see Table AI.

has only slightly diminished for many countries, particularly in Africa, where manufactures often account for less than 15 percent of merchandise exports (see Table 1).

In this context, it is also useful to assess the dependence of countries on a limited range of export commodities, and how primary export volumes (and market shares) have evolved over recent years. While a more diversified export structure is not necessarily an economic objective in and of itself, export diversification is an important way of reducing vulnerability to volatility and sustained declines in commodity prices.

Not surprisingly, the performance of real export earnings for many developing countries during the 


\section{Table I. Structure of Merchandise Exports: Selected Developing Countries, 1965 and 1990} (As a percent of merchandise exports)

\section{5}

\begin{tabular}{|c|c|c|c|c|c|c|}
\hline \multirow[b]{2}{*}{ Country } & \multicolumn{3}{|c|}{1965} & \multicolumn{3}{|c|}{1990} \\
\hline & $\begin{array}{c}\text { Fuels, } \\
\text { minerals, } \\
\text { and metals }\end{array}$ & $\begin{array}{c}\text { Other } \\
\text { primary } \\
\text { commodities }\end{array}$ & Manufactures & $\begin{array}{c}\text { Fuels, } \\
\text { minerals, } \\
\text { and metals }\end{array}$ & $\begin{array}{c}\text { Other } \\
\text { primary } \\
\text { commodities }\end{array}$ & Manufactures \\
\hline \multicolumn{7}{|l|}{ Africa } \\
\hline Burundi & 0 & 94 & 6 & 0 & 98 & 2 \\
\hline Côte d'Ivoire & 2 & 93 & 5 & 10 & 80 & 10 \\
\hline Kenya & 13 & 77 & 10 & 19 & 70 & II \\
\hline Mauritania & 94 & 5 & I & 81 & 13 & 6 \\
\hline Senegal & 9 & 88 & 3 & 22 & 56 & 22 \\
\hline Tanzania & 1 & 86 & 13 & 5 & 84 & 11 \\
\hline \multicolumn{7}{|l|}{ Asia } \\
\hline Malaysia & 34 & 60 & 6 & 19 & 37 & 44 \\
\hline Pakistan & 2 & 62 & 36 & 1 & 29 & 70 \\
\hline Philippines & 11 & 84 & 5 & 12 & 26 & 62 \\
\hline Sri Lanka & 0 & 99 & 1 & 6 & 47 & 47 \\
\hline Thailand & 11 & 86 & 3 & 2 & 34 & 64 \\
\hline \multicolumn{7}{|l|}{ Latin America } \\
\hline Argentina & I & 93 & 6 & 6 & 59 & 35 \\
\hline Bolivia & 93 & 4 & 4 & 69 & 27 & 14 \\
\hline Brazil & 9 & 83 & 8 & 16 & 31 & 53 \\
\hline Colombia & 18 & 75 & 7 & 32 & 42 & 26 \\
\hline Mexico & 22 & 62 & 16 & 43 & 13 & 54 \\
\hline Uruguay & 0 & 95 & 5 & 0 & 60 & 40 \\
\hline
\end{tabular}

Source: World Bank, World Development Report, 1992 (Washington, 1992).

1980 s and 1990s has been closely linked to the countries' success in diversifying their export base, as well as their ability to expand their primary commodity export volumes. As Table 2 highlights for a selected group of countries, the Asian experience is characterized by a marked shift toward exports of manufactures and strong increases in real export earnings; at the other extreme, the situation in Africa can be generally described as one where continued reliance on primary commodity exports has resulted in a marked and persistent deterioration in real export earnings. But it is noteworthy that the group of countries in Asia and Latin America that has achieved the largest increase in export diversification has not done so at the expense of the production of commodities; these countries are also among those that have increased the volume of commodity exports the most.

This paper reviews the major recent developments in international non-oil commodity markets and policy issues that have arisen in connection with these developments. ${ }^{4}$ Its purpose is essentially threefold. First, the paper reviews some of the key characteristics of commodity prices that may be useful in formulating the policy response to commodity price shocks and in assessing the outlook for commodity prices over the near term. ${ }^{5}$ For instance, the usefulness of a stabilization fund will depend crucially on whether the shocks to commodity prices are primarily of a temporary or of a more permanent nature. ${ }^{6}$ On a similar note, the

\footnotetext{
${ }^{4}$ The technical work that provides the background for the analysis is included in two recent studies on the subject by Borensztein and Reinhart (1994) and Reinhart and Wickham (1994). The technical background to the discussion of the macroeconomic response to uncertainty created by commodity price shocks is provided in Ghosh and Ostry (1994).

sUnless otherwise noted, real commodity prices refer to the IMF all nonfuel commodity price index deflated by the IMF index of manufacturing export unit values (MEUV) of industrial countries. Both indices are in U.S. dollars. This is the traditional deflator used in analysis of international commodity prices.

${ }^{6}$ See Cuddington and Urzua (1989) and Deaton (1992).
} 


\section{Table 2. Real Export Earnings, 1970-92' (Average annual percent change)}

\begin{tabular}{lrr}
\hline & & \\
Country & $1970-79$ & $1980-92$ \\
\hline Africa & & \\
Burundi & 3.7 & -3.7 \\
Côte d'lvoire & 6.1 & -8.2 \\
Kenya & -3.0 & -5.4 \\
Mauritania & -6.6 & 13.2 \\
Senegal & -0.9 & 3.6 \\
Tanzania & -2.7 & -5.6 \\
Asia & & \\
Malaysia & 8.9 & 8.1 \\
Pakistan & 2.6 & 6.1 \\
Philippines & 3.8 & 3.5 \\
Sri Lanka & 1.2 & 5.9 \\
Thailand & 9.9 & 10.7 \\
Latin America & & \\
Argentina & 2.5 & 2.2 \\
Bolivia & 9.1 & -0.7 \\
Brazil & 7.4 & 4.6 \\
Colombia & 7.4 & 8.5 \\
Mexico & 11.3 & 5.6 \\
Uruguay & 0.5 & 4.3 \\
& & \\
Sorceinta & & \\
\hline
\end{tabular}

Source: International Monetary Fund, World Economic Outiook, various issues.

'Real export earnings defined as value of exports deflated by import unit values.

potential benefits that can be obtained from stabilization funds, or more generally from precautionary savings, will be greater the more volatile and uncertain the environment. ${ }^{7}$ Hedging strategies, as well, acquire greater importance as volatility and uncertainty increase.

Second, the study provides an assessment of the economic fundamentals determining the decline in commodity prices. Analyses of commodity market developments have usually focused on macroeconomic conditions in industrial countries as the principal factor affecting commodity prices $^{8}$ To understand commodity price developments in the last decade, however, it is necessary to consider the impact of the expansion in commodity supplies and of economic developments in transition economies. The large increases in the volume of commodity production have apparently been linked to a number of factors, including increasing openness and export incentives in developing countries (in some

\footnotetext{
${ }^{7}$ See, for example, Ghosh and Ostry (1994).

${ }^{8}$ See, for instance, Dornbusch (1985) and Chu and Morrison (1986).
}

cases motivated by the debt crisis of the 1980s), productivity-enhancing technological improvements, agricultural policies in the largest industrial countries, and, more recently, the surge in the exports of various metals from the former Soviet Union. In addition, this paper examines how recent macroeconomic developments in transition economies, such as the sharp contraction in aggregate demand in the former Soviet Union, have affected the behavior of real commodity prices. The role played by international commodity agreements is also discussed.

Third, the paper reviews the main policy issues raised by the recent behavior of commodity prices. It re-examines to what extent there is a role for government intervention and assesses the relative merits of alternative intervention strategies. An important distinction is drawn between two sets of motives for government intervention. First, there is the issue of how to react to temporary fluctuations in commodity prices and to their volatility. The use of price and income stabilization funds, agricultural trading boards, and hedging strategies are some of the policies designed to deal with this type of problem. Second, there are the issues raised by the sustained decline in the real price of commodities. This decline poses the question of the desirability of structural policies that foster productivity increases in the primary commodity-producing sector and that encourage export diversification.

Concerning the characteristics of the evolution of commodity prices, three main empirical regularities emerge from the analysis. First, the recent weakness in real commodity prices appears to be primarily of a secular, persistent nature, and not the product of a large, temporary deviation from trend. Second, the relative importance of noncyclical or "permanent" shocks varies considerably across commodity groupings. Thus, while permanent shocks are estimated to account for only 30 percent of the variance of metals prices, they account for about 85 percent of the variance of beverage prices. And third, the volatility of commodity prices has risen steadily and considerably since the early 1970 s, particularly in the once relatively stable food grouping.

The analysis of the major factors behind the observed behavior of commodity prices reveals that conventional factors, such as the prevailing macroeconomic conditions in industrial countries, are estimated to have contributed only in a limited way to the recent weakness in real commodity prices and that the expansion in the supply of commodities played a fundamental role. In addition, while output changes in Eastern Europe and the former Soviet Union traditionally played a relatively minor role in price developments, they 
acquired an increasingly important role in the post-1988 period.

Regarding the policy response to temporary price fluctuations, a case has traditionally been made for governments to influence prices received by small commodity producers in order to smooth their income. However, there is some evidence indicating that private agents in developing countries may be more resourceful than usually believed in finding ways to smooth consumption. In contrast, governments have shown a tendency to display less foresight, for example, by overspending during temporary booms. Thus, institutional arrangements, such as stabilization funds, that establish a rule for government behavior concerning revenue accruing from commodity exports can be, in principle, useful tools. However, trading boards and other devices for governments to smooth incomes of producers can also easily become distortional. In addition, the development of financial markets for derivative securities (futures and options) and other kinds of commodity-related securities offers ways for exporting countries to trade away the risk associated with commodity price volatility at relevant time horizons and would diminish the need for income- or consumption-smoothing policies.

With respect to possible policy responses to longer-term declines in commodity prices, an environment conducive to export diversification is important, but it is not desirable to introduce distortions in order to move resources away from primary commodity production. Indeed, the experience of the high-performing Asian countries indicates that establishing a dynamic agricultural sector is an important phase in the diversification process. There may, however, be a role for government in this process to the extent that information problems or imperfections in financial markets prevent prices from transmitting the correct signals, or agents from responding to them. 


\section{Characteristics of Commodity Price Behavior}

T he principal aim of this section is to assess the nature of commodity price shocks and to determine to what extent the recent weakness in commodity prices is associated with reversible cyclical forces, or in what measure it is part of a longer-term secular decline. In addition, some of the more general stylized facts about the behavior of commodity prices that may be useful in formulating a policy response to commodity price shocks are presented. These include: (a) an analysis of the persistence, duration and other features of the commodity price cycle; (b) a quantitative assessment of the relative importance of "permanent" shocks in explaining the variation in real commodity prices; and (c) an assessment of whether the nature of the shocks to commodity prices has changed over recent years and whether the volatility of commodity prices has increased over time. ${ }^{9}$

\section{Trends and Cycles in Commodity Prices}

As noted earlier, it is critical, when formulating a policy response to a commodity price shock, to disentangle the trend from the cycle; the former is associated with permanent (or at least very persistent) changes while the latter is temporary in nature. Similarly, when assessing the near-tomedium-term outlook for commodity prices it is important to have an idea to what extent the recent weakness is cyclical, and therefore potentially reversible, or in what measure it appears to be associated with more persistent secular forces that have a lower probability of being reversed.

There are a number of statistical methodologies for disentangling the trend from the cycle in real commodity prices, and the detailed results are presented in Reinhart and Wickham (1994). ${ }^{10}$ For

\footnotetext{
${ }^{9}$ Quarterly data for the period 1957:I to 1993:II constituted the sample. The analysis covers the all non-oil commodity, beverages, foods, and metals indices.

$10 \mathrm{~A}$ full description of the various methodologies used and the full results can be found in Reinhart and Wickham (1994). The illustration provided here is based on the Beveridge-Nelson decomposition technique. The shorter sample reflects the loss of observations associated with this procedure.
}

illustrative purposes, Chart 4 reproduces from that paper the estimated permanent or trend component for real commodity prices using one of the available statistical methodologies. The difference between the estimated permanent or trend component and the actual price series constitutes the estimated cyclical or temporary component. ${ }^{11}$ The essence of the results, which is confirmed in major part by alternative estimates of the trend and cycle components, is as follows. Large deviations from trend were evident in the all non-oil commodity, food, and metals indices during 1973, at the time of the first oil shock. For the beverages index, the largest deviation from trend during the sample took place during 1977 and is associated with a supply shock. ${ }^{12}$ With the possible exception of the metals basket, for which the actual price is below the estimated trend since late 1990, all the other indices are currently estimated to be quite close to their permanent or trend component. This observation would seem to suggest that the major part of the price decline during recent years is due to more persistent causes than, say, a cyclical downturn in economic activity in the major industrial countries.

The evolution of the permanent component also changes considerably during the sample period. While during the 1960 s and up to the first oil shock all prices were relatively stable, the trend becomes markedly negative from the mid-1970s onwards (for beverages somewhat later). In addition, the cycles are correlated across commodity groupings. The temporary shocks that drive the cycle can exhibit differing degrees of persistence. From a policy perspective, the difference between permanent changes

\footnotetext{
${ }^{11}$ It should be emphasized that the available methodologies attempt to determine ex post the nature of commodity price shocks; this does not imply that recent trends can simply be extrapolated into the future. The trend is not necessarily a simple linear function, but can itself vary over time. See Chart 4.

12 Since coffee has a large weight in the beverage index, this price spike is associated with a severe frost in Brazil that did considerable damage to the trees.
} 


\section{Chart 4. Real Non-Oil Commodity Prices: Trends and Cycles,} 1962:1-1993:II
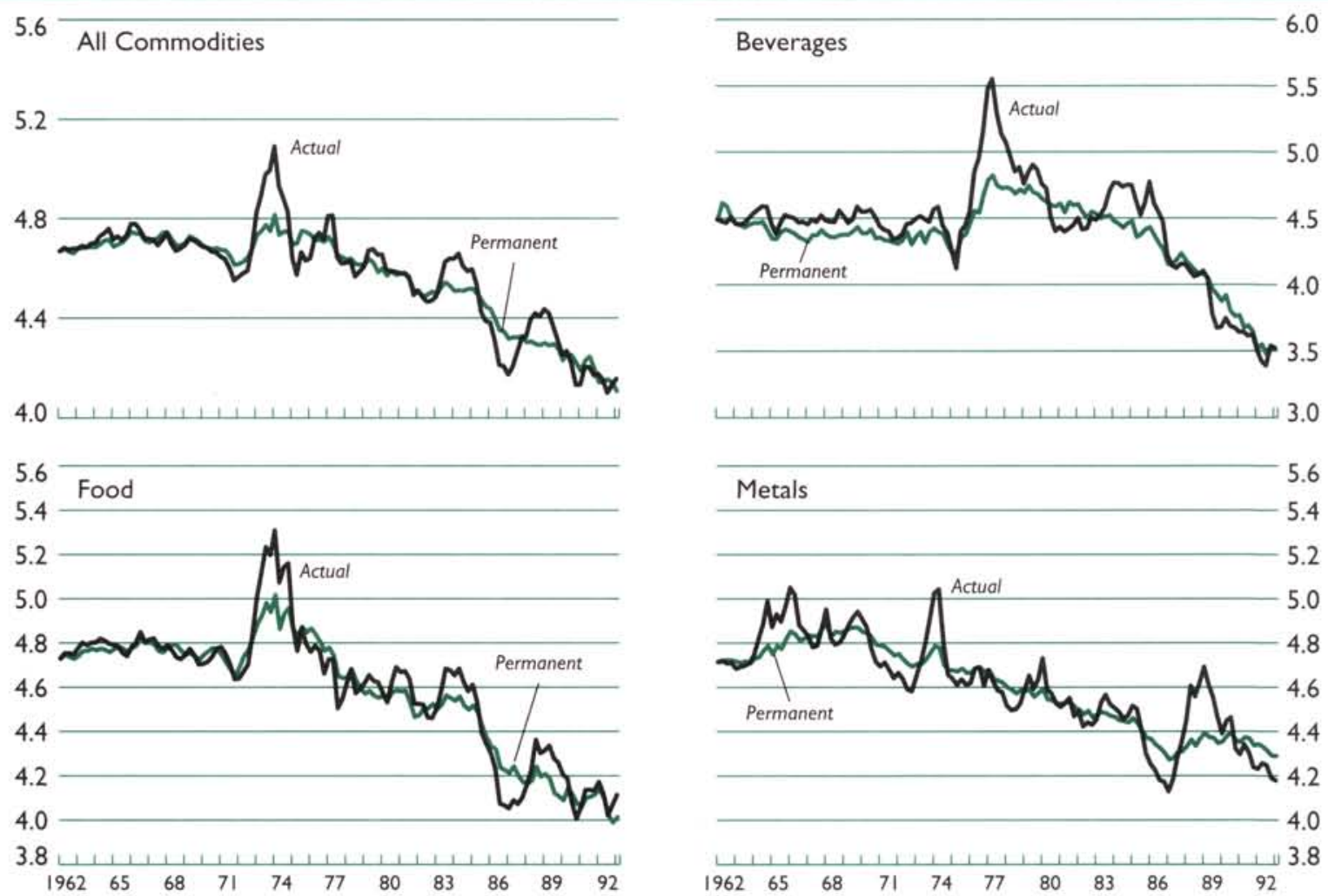

Sources: IMF, International Financial Statistics; and Reinhart and Wickham (1994).

and temporary, but highly persistent ones may not be that significant as attempts to smooth out their consequences would run into similar difficulties. An analysis of the duration and persistence of the cycle indicates that it may take quite some time for a temporary shock to fade away almost completely. Shocks to the metals index are the least persistent (becoming arbitrarily small in 6 to 7 quarters) and most persistent for beverages (12 to 13 quarters). ${ }^{13}$ The temporariness of the cycle also seems to vary considerably across individual commodities (Cuddington (1992)). . $^{14}$

In sum, there is no compelling evidence to suggest that the price weakness that prevailed through

\footnotetext{
${ }^{13}$ See Reinhart and Wickham (1994).

${ }^{14} \mathrm{It}$ is worth noting that the duration of the cycles for the allcommodity index corresponds rather well with the duration of the business cycle (as defined and measured by the National Bureau of Economic Research) in the United States.
}

mid-1993 was part of an anomalous cycle. This means that the decline in commodity prices of the past decade should be interpreted as being largely permanent, in the sense that there are no forces in play to reverse that decline automatically, as would be the case with purely cyclical fluctuations. It should be noted, however, that the permanent or trend component of commodity price movements can itself change over time and be partly random. While there is some evidence that the downward trend has steepened in the recent past, it cannot, of course, be ruled out that factors influencing the trend will be more positive in the future.

\section{Size of the Permanent Component of Price Shocks}

While Chart 4 provides a useful visualization of cyclical and trend movements in real commodity 
prices, it does not provide a quantitative measure of the relative importance of permanent shocks in explaining the variance of changes in real commodity prices. Table 3 summarizes the main findings on the extent to which price changes are attributable to permanent price shocks. For each of the four commodity indices, permanent shocks play a role in explaining the variance of commodity prices. However, their relative importance varies considerably across commodity groupings. Permanent shocks are least important for metals (29 percent of the variance of yearly changes) and most important ( 85 percent) for beverages. The all non-oil commodity index, reflecting the differing characteristics of its components, falls in the middle of the range, with permanent shocks accounting for about 45 percent of the variance of yearly changes. ${ }^{15}$ For the two price indices with the largest permanent component-beverages and food-there is evidence that even the temporary component of these series exhibits a high degree of persistence. The latter observation would indicate that, even when the shock is temporary, the costs associated with a price (or incomes) stabilization policy could be quite large.

\section{Increasing Volatility of Commodity Prices}

In addition to assessing whether a commodity price is driven primarily by permanent or transitory shocks, it is important to consider other aspects of the nature of the shocks when designing policy. For instance, even if all shocks are temporary, there are relatively few gains from setting up a stabilization fund and/or hedging if the variance of prices is small and large shocks are rare. The benefits that can be obtained from stabilization funds or, more generally, from precautionary savings will increase in a more volatile and uncertain environment, as greater uncertainty in a country's export revenue stream increases the value to that country of accumulating assets as a means of protecting itself against future shocks. ${ }^{16}$ Similarly, hedging strat-

\footnotetext{
${ }^{15}$ This result is in line with the findings of Cuddington and Urzua (1989), who, using annual data for an all non-oil commodity index for the period $1900-83$, find that about 39 percent of the shocks to real commodity prices are permanent.

${ }^{16}$ See Ghosh and Ostry (1994).
}

\section{Table 3. Share of the Variance of Changes in Real Non-Oil Commodity Prices Due to Permanent Shocks, 1957-92'}

\begin{tabular}{cccc} 
All Commodities & Beverages & Food & Metals \\
\hline 0.448 & 0.846 & 0.731 & 0.287
\end{tabular}

IAnnual data were used. All commodity price indices are deflated by the export unit values of manufactures. A fuller description of the methodology used and more detailed results are presented in Reinhart and Wickham (1994).

egies acquire greater importance as volatility increases and the probability of large, destabilizing shocks becomes higher.

Statistical analysis indicates that shocks to commodity prices have been larger in the latter part of the sample than in the comparatively stable 1950 s and 1960s. Several results of this exercise are worth noting. First, the average price is markedly lower during the most recent sample, consistent with the presence of a negative trend, or a series of downward jumps in average prices. Second, there is a sustained and sharp increase in the variance of commodity prices. ${ }^{17}$ This is evident in all the indices but is most pronounced in the all non-oil commodities and food groupings; for the all non-oil commodities index volatility increases fivefold, while for food the increase in the volatility measure is sixfold. These results can be observed in Chart 5, which plots the volatility indicator over the 1972-93 period. Following the relative tranquillity of commodity prices during the 1950 s and 1960 s, the sharp increase in volatility in the early 1970 s followed a period of expansive monetary policy in some industrial countries, the breakdown of the Bretton Woods exchange rate system, and came on the heels of the first oil shock. However, volatility has apparently remained high during the 1980 s and 1990 s. ${ }^{18}$

\footnotetext{
${ }^{17}$ This feature has also been discussed in Deaton (1992) and Deaton and Laroque (1992).

${ }^{18} \mathrm{It}$ is interesting to note that from a long-term perspective the relative tranquillity of the $1950 \mathrm{~s}$ and 1960 s contrasts quite sharply with commodity price behavior prior to World War II and after 1974. For a discussion of volatility over the longer term, see Boughton (1991).
} 
Chart 5. Rising Volatility in Real Non-Oil Commodity Prices, 1972:1-1993:II

(Coefficients of Variation)

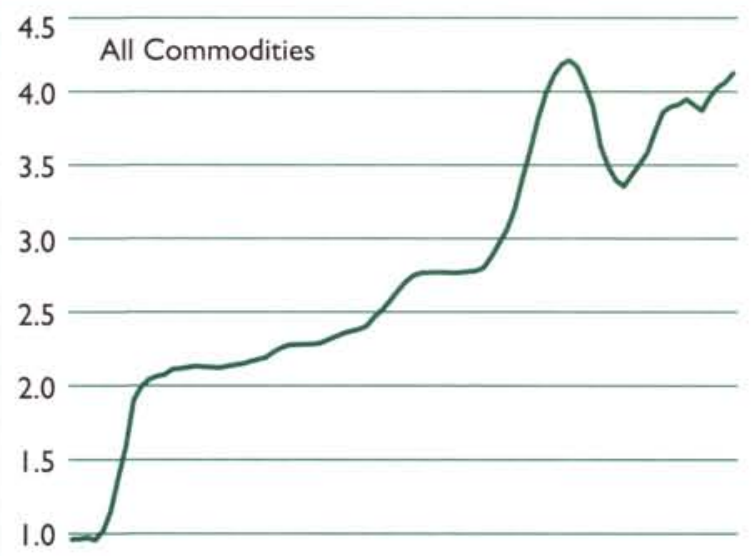

$0.5\llcorner|+|+|+|+|+||+||+|||+\mid$
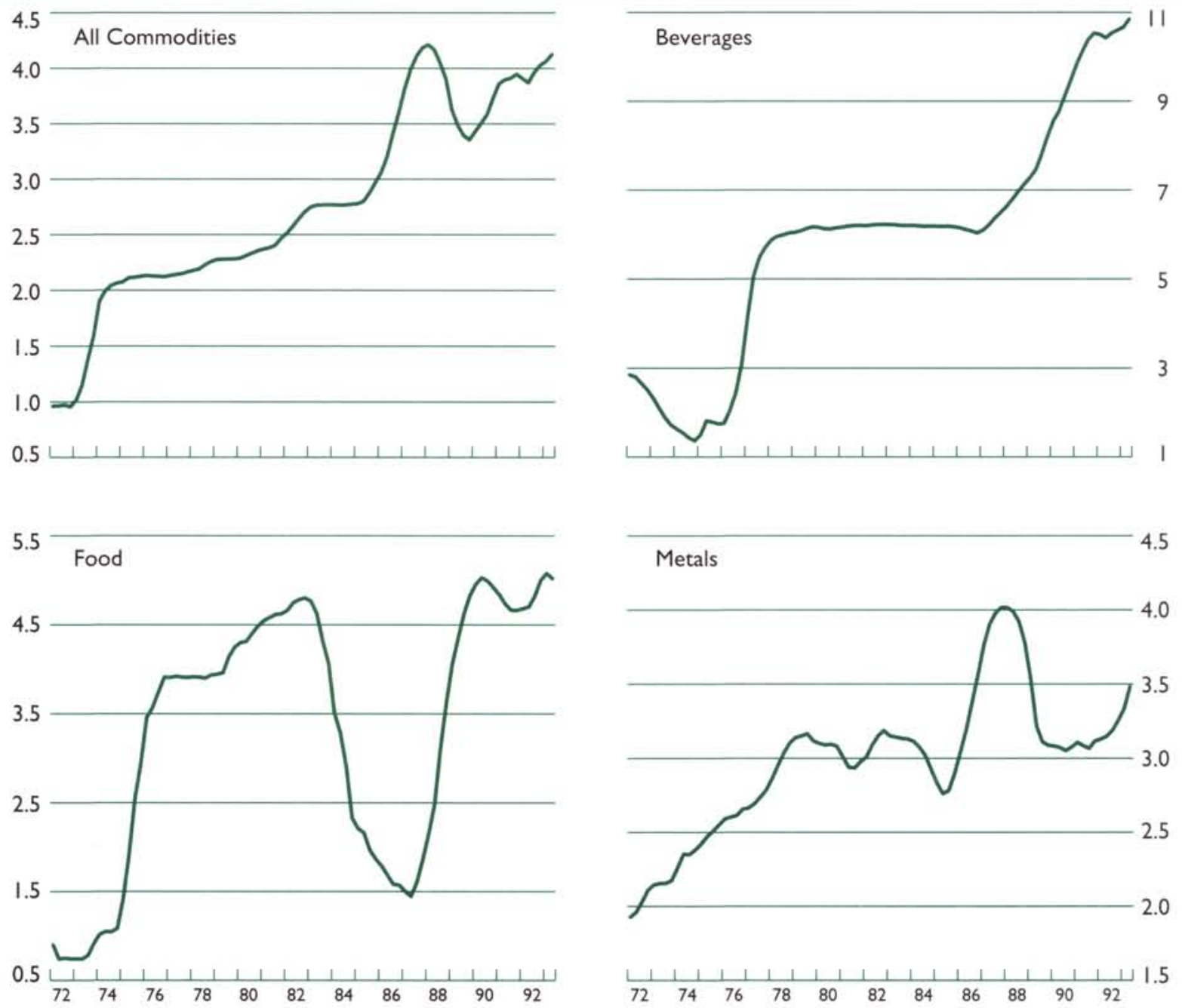

Sources: IMF, International Financial Stotistics; and Reinhart and Wickham (1994).

Note: The coefficient of variation is based on 15-year moving averages and 15-year standard deviations that are backward looking, hence the observation for 1972:1, for instance, is based on data from 1957:11-1972:1. 


\section{Determinants of Commodity Price Movements}

ssessing the evolution of commodity prices by applying time-series methods has shed some light on the persistence and increased volatility of shocks in commodity markets. This section complements those findings by examining the economic fundamentals that determined the decline in commodity prices and their relative importance. To the extent that such economic fundamentals explain a substantial part of the documented decline in commodity prices, this analysis may assist in the assessment of the near-term prospects in commodity markets.

A number of reasons have been put forward to explain the weakness in commodity prices. Among those explanations, the response in developing countries to the effects of the debt crisis of the 1980 s and, more recently, the economic developments in the economies in transition in Eastern Europe and the former Soviet Union stand out as major shocks that are likely to have exerted considerable influence on commodity markets. To evaluate those factors in a more systematic way, this section will also make use of the results from a simple aggregate econometric model of commodity price determination (Borensztein and Reinhart (1994)). Within the framework set out in that paper, the distinct importance of supply-side factors, in addition to demand factors, in the recent decline in commodity prices becomes evident.

\section{Economic Growth and the Demand for Commodities}

Analyses of commodity market developments have usually focused on the macroeconomic conditions in industrial countries as the principal factor affecting commodity prices. Given the role of many commodities as inputs for production by manufacturing industries, their demand is closely related to the level of industrial economic activity, the major part of which takes place in industrial countries. ${ }^{19}$

\footnotetext{
${ }^{19}$ Even with an increasing fraction of industrial activity taking place outside the group of industrial countries, indicators of economic activity in that group are still relatively good proxies for world demand because of international linkages.
}

Therefore, the trend decline in commodity prices is, at least partially, related to the secular slowdown in the growth of real output in the industrial countries that has been observed since the early 1970s, with 1973 marking the end of the strong postwar expansion phase for most countries. ${ }^{20}$

In addition to the slowdown in growth, a declining intensity of resource use for some commodities, particularly in industrial countries, has contributed to reduced rates of growth in commodities demand. Since 1974, for example, the growth in consumption of six major metals by the Group of Seven industrial countries has decelerated sharply and, in some cases, consumption has declined in absolute terms (Table 4). While there are some differences between countries and between particular metals, the consumption slowdown is quite general and is linked to the slowdown in real economic growth. However, Table 4 clearly shows the decline in the intensity of metals use as indicated by average annual changes in consumption per unit of real output (real GDP). Thus, in addition to the slowdown or decline in demand growth for metals engendered by lower real output growth, these indicators of intensity of metals use provide summary information suggesting the effects of longer-term trends in technological innovation or in structural factors that govern metal resource usage in the industrial countries. ${ }^{21}$

Various explanations have been put forward for the trends observed in the intensity of metals use in the industrial countries. Some of these explanations stress the changing composition of output: the shift away from manufacturing toward services; the declining share in GDP of gross domestic investment, including structures, which is more metal intensive than other components of expenditure; and, more recently, declining output in the

\footnotetext{
20Perron (1989), among others, dates the start of the slowdown in gross domestic product (GDP) growth at the first quarter of 1973 . For a discussion of the factors behind the slowdown in growth, see, for example, Adams, Fenton, and Larsen (1987).

${ }_{21}$ Tilton (1990) has shown that this pattern holds more broadly for member countries of the Organization for Economic Cooperation and Development.
} 
Table 4. Intensity of Metals Use in Major Industrial Countries (Average percentoge changes)

\begin{tabular}{|c|c|c|c|c|c|c|c|c|c|}
\hline & \multicolumn{3}{|c|}{$1962-73$} & \multicolumn{3}{|c|}{$1974-81$} & \multicolumn{3}{|c|}{$|982-9|$} \\
\hline & $\begin{array}{l}\text { Consump- } \\
\text { tion }\end{array}$ & $\begin{array}{l}\text { Real } \\
\text { GDP }\end{array}$ & $\begin{array}{l}\text { Intensity } \\
\text { of use I }\end{array}$ & $\begin{array}{c}\text { Consump- } \\
\text { tion }\end{array}$ & $\begin{array}{l}\text { Real } \\
\text { GDP }\end{array}$ & $\begin{array}{l}\text { Intensity } \\
\text { of use }\end{array}$ & $\begin{array}{c}\text { Consump- } \\
\text { tion }\end{array}$ & $\begin{array}{l}\text { Real } \\
\text { GDP }\end{array}$ & $\begin{array}{l}\text { Intensity } \\
\text { of use }\end{array}$ \\
\hline \multicolumn{10}{|l|}{ Aluminum } \\
\hline United States & 9.3 & 3.5 & 4.1 & -0.6 & 2.1 & -2.9 & 0.3 & 2.3 & -2.1 \\
\hline Japan & 20.3 & 9.5 & 13.0 & 1.1 & 3.6 & -2.6 & 4.9 & 4.2 & 0.7 \\
\hline France & 7.4 & 4.9 & 3.1 & 3.0 & 2.5 & 0.4 & 3.2 & 2.3 & 0.9 \\
\hline Germany & 9.6 & 4.2 & 6.3 & 3.2 & 1.9 & 1.1 & 3.0 & 2.2 & 0.7 \\
\hline Italy & 10.5 & 5.3 & 7.7 & 4.1 & 3.4 & 0.3 & 5.0 & 2.3 & 2.6 \\
\hline United Kingdom & 5.2 & 3.1 & 1.7 & -4.1 & 0.8 & -4.9 & 2.5 & 2.5 & - \\
\hline Canada & 8.6 & 5.3 & 1.4 & 1.3 & 3.8 & -2.5 & 4.5 & 2.4 & 2.0 \\
\hline \multicolumn{10}{|l|}{ Copper } \\
\hline United States & 4.7 & 3.5 & -0.6 & 0.4 & 2.1 & -1.9 & 0.6 & 2.3 & -1.8 \\
\hline Japan & 11.2 & 9.5 & 4.2 & 1.8 & 3.6 & -2.0 & 2.8 & 4.2 & -1.4 \\
\hline France & 4.6 & 4.9 & -0.2 & 1.2 & 2.5 & -1.3 & 1.3 & 2.3 & -1.1 \\
\hline Germany & 2.7 & 4.2 & 0.2 & 0.7 & 1.9 & -1.3 & 3.0 & 2.2 & 0.8 \\
\hline Italy & 3.4 & 5.3 & 0.3 & 2.9 & 3.4 & -0.5 & 2.7 & 2.3 & 0.3 \\
\hline United Kingdom & 0.4 & 3.1 & -5.1 & -5.4 & 0.8 & -6.2 & -2.0 & 2.5 & -4.4 \\
\hline Canada & 6.1 & 5.3 & -2.5 & 0.8 & 3.8 & -3.0 & -1.4 & 2.4 & -3.9 \\
\hline \multicolumn{10}{|l|}{ Lead } \\
\hline United States & 3.5 & 3.5 & -0.7 & -2.0 & 2.1 & -4.1 & 1.1 & 2.3 & -1.2 \\
\hline Japan & 6.9 & 9.5 & -1.5 & 6.1 & 3.6 & 2.2 & 1.1 & 4.2 & -3.0 \\
\hline France & 3.1 & 4.9 & 0.8 & -0.3 & 2.5 & -2.8 & 2.0 & 2.3 & -0.3 \\
\hline Germany & 3.5 & 4.2 & -0.7 & -0.3 & 1.9 & -2.3 & 2.4 & 2.2 & 0.1 \\
\hline Italy & 9.0 & 5.3 & 6.9 & 2.2 & 3.4 & -1.4 & 0.2 & 2.3 & -2.1 \\
\hline United Kingdom & 0.3 & 3.1 & -4.2 & -0.4 & 0.8 & -1.1 & 0.1 & 2.5 & -2.4 \\
\hline Canada & 3.8 & 5.3 & -1.7 & 10.7 & 3.8 & 6.6 & -3.8 & 2.4 & -6.2 \\
\hline \multicolumn{10}{|l|}{ Zinc } \\
\hline United States & 7.1 & 3.5 & 2.0 & -5.9 & 2.1 & -8.0 & 0.3 & 2.3 & -2.1 \\
\hline Japan & 11.4 & 9.5 & 2.3 & -1.0 & 3.6 & -4.5 & 2.0 & 4.2 & -2.1 \\
\hline France & 4.0 & 4.9 & 1.1 & 0.4 & 2.5 & -2.2 & 0.8 & 2.3 & -1.5 \\
\hline Germany & 3.3 & 4.2 & -0.3 & -1.2 & 1.9 & -3.3 & 3.9 & 2.2 & 1.7 \\
\hline Italy & 7.9 & 5.3 & 3.0 & 1.1 & 3.4 & -2.5 & 2.8 & 2.3 & 0.5 \\
\hline United Kingdom & 1.5 & 3.1 & -2.0 & -4.8 & 0.8 & -5.7 & -0.3 & 2.5 & -2.7 \\
\hline Canada & 7.6 & 5.3 & 0.2 & 0.9 & 3.8 & -2.8 & -0.5 & 2.4 & -2.9 \\
\hline \multicolumn{10}{|l|}{ Tin } \\
\hline United States & 1.3 & 3.5 & -3.5 & -4.2 & 2.1 & -6.3 & -0.4 & 2.3 & -2.8 \\
\hline Japan & 8.6 & 9.5 & 1.6 & -2.1 & 3.6 & -5.5 & 1.3 & 4.2 & -2.7 \\
\hline France & 1.7 & 4.9 & -2.3 & -3.3 & 2.5 & -5.7 & -0.8 & 2.3 & -3.0 \\
\hline Germany & -0.2 & 4.2 & -0.2 & -1.9 & 1.9 & -3.9 & 4.0 & 2.2 & 1.8 \\
\hline Italy & 4.2 & 5.3 & -1.3 & -6.8 & 3.4 & -10.2 & 3.3 & 2.3 & 1.0 \\
\hline United Kingdom & -1.4 & 3.1 & -4.6 & -5.5 & 0.8 & -6.3 & -0.5 & 2.5 & -2.9 \\
\hline Canada & 4.2 & 5.3 & -2.0 & -4.0 & 3.8 & -7.5 & -2.5 & 2.4 & -4.8 \\
\hline \multicolumn{10}{|l|}{ Nickel } \\
\hline United States & 5.0 & 3.5 & -1.0 & -2.1 & 2.1 & -4.2 & -0.5 & 2.3 & -2.8 \\
\hline Japan & 17.3 & 9.5 & 9.2 & 1.4 & 3.6 & -2.2 & 6.0 & 4.2 & 1.7 \\
\hline France & 6.8 & 4.9 & 0.2 & 2.8 & 2.5 & 0.2 & 1.7 & 2.3 & -0.6 \\
\hline Germany & 8.8 & 4.2 & 4.2 & 3.1 & 1.9 & 0.9 & 1.4 & 2.2 & -0.9 \\
\hline Italy & 10.3 & 5.3 & 7.8 & -0.4 & 3.4 & -3.9 & 5.4 & 2.3 & 3.0 \\
\hline United Kingdom & 2.3 & 3.1 & -4.3 & -3.2 & 0.8 & -4.1 & 3.7 & 2.5 & 1.1 \\
\hline Canada & 8.3 & 5.3 & 0.6 & -0.4 & 3.8 & -4.0 & 8.2 & 2.4 & 5.4 \\
\hline
\end{tabular}

Source: World Bank.

Intensity of use measured as the average annual change in the ratio of consumption to real GDP. 
defense-related industries. Other explanations focus on the role of resource-saving technologies and the process of materials substitution. High rates of growth in metals consumption during the 1960 s were by the early 1970 s generating widespread fears about the future availability and price of depletable resources (such as nonferrous metals), the so-called "Limits to Growth" hypothesis. ${ }^{22}$ Rising metals prices in the late 1960 s, reinforced by the price spike in 1973 that was one of the events surrounding the first major oil shock, are believed to have set in motion a surge in resource-saving innovation and material substitution that is not likely to be reversed. ${ }^{23}$

Much less information is available on intensity of metals use outside the industrial countries. For the former Council for Mutual Economic Assistance (CMEA) countries, Dobozi (1990) shows that the period of growing metals consumption and rising intensity of use also came to an end in the mid-1970s as output growth in the former CMEA countries also slowed. However, rather than falling as in the industrial countries, the intensity of metals use stagnated or showed little change before declining quite sharply in the $1980 \mathrm{~s}$. With regard to developing countries, the rapid pace of industrialization in the Asian region and in parts of Latin America in the 1960 s through to the early 1980 s has been linked with rising intensity of metals use, and appears to be related to the relatively high levels of gross domestic investment being maintained during this period.24 The subsequent picture is more mixed as external financing difficulties lowered investment and growth rates in many developing countries, particularly in Africa and Latin America. Still, the observed trend toward less metalintensive technologies in industrial countries implies that overall metals demand has not grown as rapidly, contributing to the overall weakness in commodity prices.

\section{Expansion in Supply}

A remarkable feature of developments in commodity markets in the 1980 s has been the vigorous growth in the volume of imports of commodities (Chart 6). Since 1983, the volume of imports of

\footnotetext{
22Meadows and others (1972).

${ }^{23}$ There is evidence consistent with the hypotheses. Technological progress, for example, has over time permitted metal beverage and food containers (chiefly aluminum and tinplate) to be made much thinner. In the area of materials substitution, plastics, ceramics, and composites have increasingly been used, for example, in automobile manufacturing as automakers endeavored to make lighter and more fuel-efficient cars.

${ }^{24}$ See Radetzki (1990).
}

\section{Chart 6. Factors Affecting Commodity Markets}
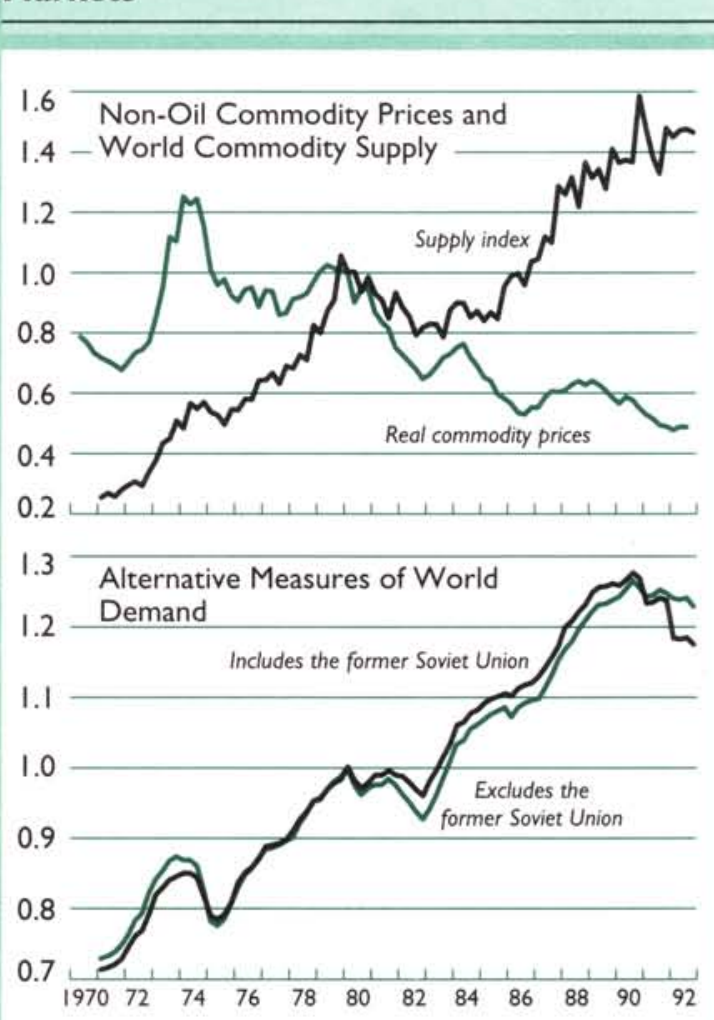

Sources: IMF, International Financial Statistics and World Economic Outlook; and Borensztein and Reinhart (1994).

non-oil commodities by industrial countries has almost doubled even though, during the same period, GDP of the industrial nations grew by less than 30 percent. Imports of non-oil commodities also grew faster than those of other goods, as world imports of all types of goods increased by approximately 70 percent in real terms during the same period. This large increase in the volume of commodity production and trade suggests the importance of supply-side factors in explaining price developments. These data suggest that the decline in prices cannot be explained by demand factors alone, and has followed from the rapid expansion in supply outstripping the growth of demand for non-oil commodities.

A number of factors contributing to this expansion in supply have been identified. For example, in the early 1980 s, many developing countries faced considerably more restricted borrowing oppor- 
tunities in international financial markets as the debt crisis unfolded. This situation required balance of payments adjustment, which brought about policies geared to encouraging exports and resulted in an expansion in commodity supplies in many developing countries. ${ }^{25}$ It could be argued that the debt crisis may have only accelerated a necessary shift from import substitution toward exportoriented development strategies. Moreover, the expansion of supply has been promoted by the process of structural economic reform in many developing countries (particularly in Asia and Latin America). In particular, as countries open their economies to international trade and adjust their economic policies in a more market-oriented direction, resources tend to flow towards productive sectors with comparative advantage, which include exportable goods and, in the case of many developing countries, primary products.

In addition, a continuous process of technological innovation and productivity enhancement has contributed to a persistent expansion of supplies of numerous commodities, both in developing and industrial countries. While there are marked differences between commodities and quantification is difficult, there are a number of important examples of where these technology-driven shift factors can be shown to be important.

The diffusion of information about prices, techniques, and marketing opportunities can bring about significant increases in overall commodity supplies through new entrants into international markets. The emergence during the 1980s of, first, Malaysia and then Indonesia as major cocoa producers is one of the prime examples of this phenomenon. ${ }^{26}$ Whereas producers other than these two countries on aggregate increased production by about 15 percent between $1980-81$ and 1991-92, Malaysia and Indonesia increased their combined raw cocoa output by 500 percent in the same period; their output share rose from just under 4 percent to 17.5 percent. 27

The most remarkable examples of information diffusion and productivity growth are found in food crops. Despite demand growth, particularly due to high rates of population growth in developing countries, the rise in production has been such that real food prices have, with the exception of a brief episode in the mid-1970s, declined significantly in

\footnotetext{
${ }^{25}$ See, for example, Aizenman and Borensztein (1988) and Reinhart (1991).

${ }^{26}$ For details, see Reinhart and Wickham (1994).

${ }^{27}$ Côte d'Ivoire also expanded cocoa production in the $1970 \mathrm{~s}$ and $1980 \mathrm{~s}$ and increased its market share. However, both Ghana's and Nigeria's share declined significantly.
}

the postwar period. ${ }^{28}$ While land under cultivation has increased in many parts of the developing world, a sustained increase in yields over time has played a major role in the agricultural supplydemand equation. Advances in agroscience that have led to the development of higher-yield and more disease-resistant varieties, the increased use of fertilizers and pesticides, and the spread of irrigation, are the principal factors cited for the increases in cereal yields (see Chart 7). The improvement in yields was a more or less continuous process in the agricultural sectors of the industrial countries, but in the developing countries sharp increases occurred more recently. Highyielding wheat and rice varieties were introduced in a number of developing countries and the rate at which high-yielding varieties were adopted was often rapid.

The improvements in technology are likely to be "irreversible" in nature and are not limited to a few commodities. These developments have had widespread effects and have led to improving yields for many types of crops, including the beverages (cocoa, coffee, tea), oilseeds, vegetables, and agricultural raw materials, such as cotton. It seems likely, particularly in light of recent major advances in biotechnology, that in the future as in the past innovation and information diffusion will continue to play a significant role in increasing agricultural yields still further.

National (or transnational in the case of the European Union (EU)) agricultural policies in the industrial countries typically have also acted to stimulate output and discourage consumption, thereby reducing import needs or increasing supplies available for export. Such government intervention has been a common feature in industrial countries in the postwar period; however, a marked deterioration in the agricultural trade environment took place in the 1980s in part owing to increased subsidies to agriculture. Prices of many agricultural commodities fell considerably, the budgetary and other burdens associated with price support schemes grew, and trade disputes became increasingly acrimonious between agricultural exporters, both developed and developing. The case of wheat provides an instructive example. Price support under the EU's Common Agricultural Policy has been so effective that wheat supplies surplus to European requirements have grown over time and, assisted by the provision of export subsidies, have had to be sold on world markets. Between 1980-81 and 1991-92, wheat exports

${ }^{28}$ The price of services such as transportation, packaging, processing, and retailing has generally been rising over time, tending to offset the impact of lower "raw" food prices on retail food prices. 


\section{Chart 7. Cereal Yields by Region (In thousand kilograms/hectare)}
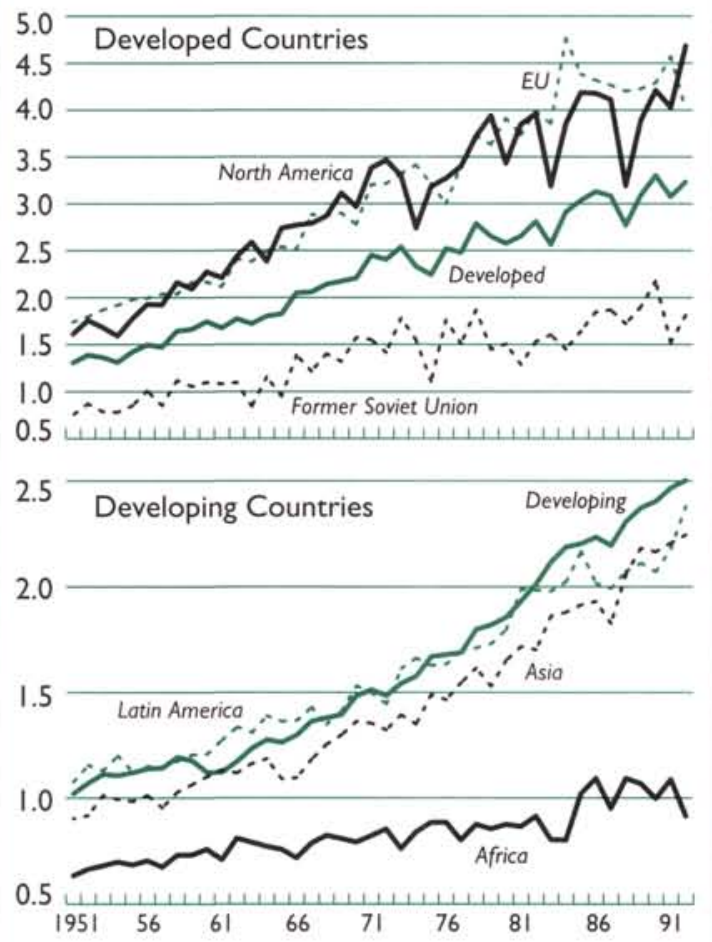

Source: Food and Agriculture Organization, Production Yearbook, 1992 (Rome: FAO. 1993).

Note: For country groupings refer to Table A2.

from the EU rose by 55 percent to nearly 22 million tons (an increase in market share from 14 percent to 20 percent). In order to counter EU penetration in its traditional markets, the United States introduced the Export Enhancement Program in 1985. The so-called "subsidy war" contributed to lower international wheat prices to the detriment of other wheat exporters.

While trade in wheat has been perhaps the most notable source of contention, other grains and commodities (e.g., meat, sugar, oilseeds) have been affected by price support schemes. There is little doubt that the agricultural policies of industrial countries have been a factor in the rapid expansion in world commodity supplies during the 1980 s, which has contributed to the weakness in prices for certain agricultural products. Liberalization measures, including a phased reduction in export subsidies to be implemented under the recently concluded Uruguay Round, should improve price prospects for a number of agricultural products. ${ }^{29}$

\section{International Commodity Agreements}

The weakening of commodity prices during the 1980s and 1990s has often been attributed in part to the breakdown of international commodity agreements (ICAs) designed to help stabilize prices and ensure a reasonable rate of return to commodity producers. ${ }^{30}$ Several such agreements were in effect during the 1970s and early 1980s, but in June 1984 the agreement covering sugar collapsed. Thereafter, other agreements followed suit or became economically moribund-tin (October 1985), cocoa (February 1988), coffee (July 1989), and natural rubber (April 1993). The immediate impact on price of a breakdown in a commodity agreement may have a large "temporary" component as, for instance, when beverage prices fell below trend from mid-1987 to mid-1989 (Chart 4). ${ }^{31}$ However, the effects of the breakdown are likely to have an important "permanent" component, as the behavior of exporters who participated in the ICA adjusts to the more competitive regime. In part, however, the breakdown of the numerous agreements reflects the difficulties of trying to influence prices by managing output or by other means in the face of developments (such as productivity increases) acting to foster an expansion in supplies.

\section{Developments in Economies in Transition}

Since 1990, another major shock affecting commodity markets has been the aftermath of economic developments in Eastern Europe and, particularly, the former Soviet Union. These countries are large participants in international trade in commodities, both as importers (especially of grains) and as exporters (particularly of metals). Their demand for imported commodities fell concomitantly with the fall in output and aggregate demand that followed the collapse of the centrally planned economic systems. Some examples of the

\footnotetext{
${ }^{29}$ Most partial and general equilibrium models suggest that real prices for most agricultural products would rise if reforms were implemented by the industrial countries. See Goldin and Knudsen (1990).

${ }^{30}$ See, for example, Maizels (1992). Conversely, it can be argued that it was the large expansion in supplies by countries outside the agreements that contributed to the ICAs' demise.

${ }^{31}$ Unless the breakdown of the ICA was fully anticipated, in which case, prices would have already reacted.
} 


\section{Table 5. Demand for Selected Commodities of the Former Soviet Union}

\begin{tabular}{|c|c|c|}
\hline $\begin{array}{l}\text { Import } \\
\text { Volumes }\end{array}$ & $\begin{array}{c}\text { Percent Change } \\
1989-92\end{array}$ & $\begin{array}{l}\text { Former Soviet Union } \\
\text { Share of World } \\
\text { Imports, 1989 } \\
\text { (In percent) }\end{array}$ \\
\hline Cocoa' & -48.1 & 4.8 \\
\hline Corn & -62.7 & 26.0 \\
\hline Tea & -55.7 & 26.9 \\
\hline Wheat ${ }^{2}$ & -17.0 & 21.3 \\
\hline
\end{tabular}

Sources: E.D. and F. Man Cocoa Ltd., Cocoa Market Report (London, various issues); International Tea Committee, Annual Bulletin of Stotistics (London, various issues); and U.S. Department of Agriculture, World Grain Situction and Outlook (Washington, various issues).

' Grindings of raw cocoa.

${ }^{2}$ Percent change is through November 1993.

decline in imports of commodities by the former Soviet Union are shown in Table 5. But the impact of the Eastern European shock was probably more pronounced in the metals markets, where the former Soviet Union is an important supplier, and where dramatic increases in exports were observed in some cases. For example, zinc exports from the former Soviet Union rose by nearly 700 percent during 1989-92.

As can be seen in Table 6, the increase in exports of metals was to a large extent a reflection of the large decline in domestic demand for metals in the countries of Eastern Europe and the former Soviet Union, which responded to the declines in the level of activity in the defense industry and in other poorly competitive manufactures, and to disruptions in CMEA and interrepublican trade. Other factors may have also contributed to the increase in the volume of exports of metals, principally the increased profitability in energy-intensive metals production and exports (due to the still very low domestic price of energy), a reduction in stock levels that are no longer justified from national security or economic standpoints, and some export activity conducted principally to build up holdings of foreign assets.

In some cases, discrepancies between domestic and international prices in the context of only partial price and trade liberalization have created arbitrage opportunities and contributed to the sharp increase in exports to western markets. ${ }^{32}$

\footnotetext{
${ }^{32}$ Effective early in 1993, domestic prices for metals were further liberalized and other steps were also taken to reduce the scope for illegal trading.
}

Table 6. Supply of Selected Commodities from the Former Soviet Union

\begin{tabular}{|c|c|c|}
\hline $\begin{array}{l}\text { Export } \\
\text { Volumes }\end{array}$ & $\begin{array}{c}\text { Percent Change } \\
1989-92\end{array}$ & $\begin{array}{l}\text { Former Soviet Union } \\
\text { Share of World } \\
\text { Exports, } 1992 \\
\text { (In percent) }\end{array}$ \\
\hline Aluminum & 219.4 & 8.3 \\
\hline Copper & 71.2 & 5.4 \\
\hline Zinc & 686.0 & 2.2 \\
\hline
\end{tabular}

Source: World Bureau of Metal Statistics, World Metol Stotistics (London, various issues).

Nickel prices in late 1992, for example, were US $\$ 1,800$ per ton for domestic deliveries to Russian state enterprises, US $\$ 3,000$ per ton on the Moscow Commodity Exchange, and nearly US $\$ 6,000$ per ton on the London Metal Exchange. Not surprisingly, smuggling and bypassing of regular domestic and export trade channels reportedly flourished during the first phase of the reform process, aided by the growth in unmarked and unprotected international borders between the newly independent states. The Baltic countries are reported to have become leading exporters of aluminum, copper, and nickel from the former Soviet Union, which suggests that much of the irregular trade took place via Russia's traditional conduits to the West. ${ }^{33}$ Overall, developments in Eastern Europe and the former Soviet Union have generated increases in exports of metals and drops in imports of grains and other commodities, contributing to the observed weakness in the aggregate prices of primary products.

In general terms, it does not appear that developments in Eastern Europe and the former Soviet Union will affect commodity prices in a permanent way. While the restructuring of industrial production into a more marketable composition may take some time and gains in the efficiency of resource use can be expected, it will eventually induce a recovery in domestic demand; unnecessary stocks of metals will be run down, the eventual adjustment of domestic energy prices will reduce excess profitability, and a more complete price and trade liberalization-along with the privatization of industry-will eliminate incentives for arbitrage

${ }^{33}$ It seems quite likely that the customs data reported in Table 6 underestimate former Soviet Union exports to western markets. Some industry sources estimate exports of aluminum from the former Soviet Union in 1992 at about 1.2 million tons, of which it is estimated that 0.4 million tons were smuggled out. 
or capital flight-motivated exports. However, it is difficult to predict the level of metals exports that will be sustained once the transformation of the economies of the former Soviet Union republics is completed.

\section{Econometric Model Results}

The main conclusions from a recent econometric study (Borensztein and Reinhart (1994)) are that the weakness in commodity prices since 1984 cannot be explained by the two factors that have been conventionally linked to the determination of commodity prices: the level of economic activity in industrial countries and the real exchange rate of the U.S. dollar. Instead, a more accurate picture is obtained by including proxy variables that would take into account two main developments: the booming supply of exports of primary products, and the change in the net international demand for commodities of the former Soviet Union.

The improvement in predictive performance can be observed in Chart 8 , which displays the three estimated specifications. Model 1 includes conventional demand-side determinants only; model 2 adds a supply proxy to the estimated equation; and model 3 extends model 2 by incorporating the transition economies into the measure of world demand. The poor forecasting performance of model 1 after 1984 and the much more adequate performance of models 2 and 3 are evident from this chart.

The econometric results also permit an estimate to be made of the relative importance of the different factors that have determined the decline in the prices of commodities during the last decade. It suggests, for example, that industrial production in industrial countries explained 25 percent of the variation of commodity prices in the period 197184 , but just over 5 percent for $1985-88$. By contrast,

\section{Chart 8. Real Non-Oil Commodity Prices: Actual and Forecasts}

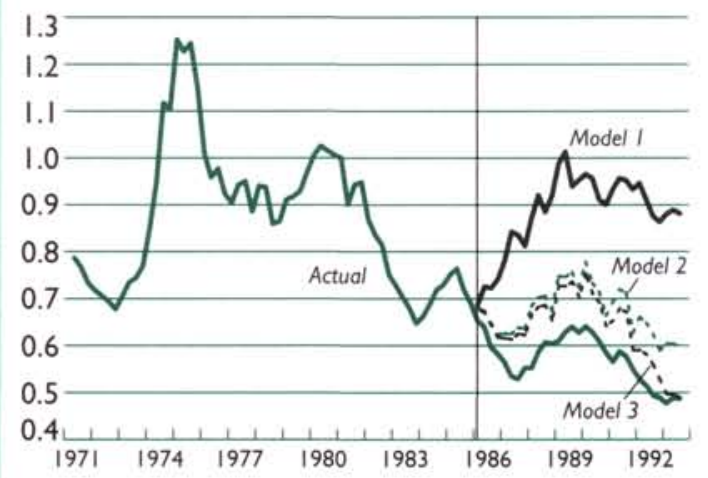

Source: Borensztein and Reinhart (1994).

the supply expansion explained about 40 percent of the variation for the period 1971-84, and over 60 percent for the period 1985-88.

The current trend toward recovery in growth in industrial countries will help to relieve downward pressures in commodity markets, but it appears unlikely that it will reverse the declines of the past decade. On the basis of the econometric results, 5 percent growth in industrial countries over the next two years (consistent with current IMF projections) would generate an increase of between $6^{1 / 2}$ and 9 percent in real commodity prices over the same period. For that increase to materialize, however, it would be necessary that other factors, in particular the trend increase in supplies and the economic developments in the former Soviet Union, exert a neutral influence on commodity markets over the next two years. 


\section{Policy Issues}

T he previous sections of the paper have examined how commodity prices have behaved over recent years and discussed possible explanations for the observed behavior. Both the volatility in real commodity prices and the downward trend experienced over recent years present serious challenges for many developing countries because of the impact on export earnings, domestic incomes (and hence private savings and investment), and government budgetary positions. The response to volatility in commodity prices, however, gives rise to issues that are quite different from those emanating from secular changes in the average level of prices. It is therefore crucial to interpret correctly market developments in each case in order to elaborate the appropriate policy response or, in fact, to consider whether a policy response is warranted at all.

\section{Temporary Price Shocks}

Temporary shocks to commodity prices affect both the private and public sectors in the commodity-producing countries. In addition, commodity price shocks can have large effects on the macroeconomic and balance of payments position of a commodity exporter, and also affect a country's access to private international financial markets because of sovereign risk considerations. When facing temporary changes in income, the optimal response by individual consumers is to use saving and borrowing in an attempt to smooth the path of consumption. Similarly, governments facing temporary changes in revenue should adjust their spending to be consistent with sustainable levels.

Traditionally the argument has been made that governments should assume most of the consequences of temporary commodity price changes and take an active role in helping to smooth income for private producers. These policy actions are often implemented through special institutional arrangements such as agricultural boards, with price stabilization as a major objective. Furthermore, international efforts to influence world prices through buffer stock operations and/or export restraints have been pursued through international commodity agreements. Another reason for intervention is that in some cases, particularly for countries with a heavy dependence on minerals and metals, there is a concern with how best to handle fluctuations in government revenues. ${ }^{34}$

\section{Role of Government in Smoothing Income}

Before examining some of the policy prescriptions that have been advanced to help deal with international commodity price variability and its macroeconomic effects, it is worth considering whether it is desirable to split the effects of temporary commodity price movements on private producers and on government.

A traditional argument for government to absorb the effects of commodity price fluctuations is based on microeconomic considerations relating to the behavior of private agents. ${ }^{35}$ If private agents bear all the commodity price risk (and supply is inelastic in the short run), they will face variable and unpredictable income streams over time, with possibly very limited opportunity to smooth consumption. Therefore, it may be optimal for the government to intervene to stabilize the prices received by private agents and thus enhance the welfare of risk-averse individuals by permitting smoother income and consumption streams. However, some additional assumptions are necessary to support this argument. For example, it can be argued that producers face liquidity constraints, because of underdeveloped financial systems or owing to information problems, so that it is not possible for them to borrow when commodity prices are temporarily low. ${ }^{36}$ The implicit assump-

\footnotetext{
${ }^{34} \mathrm{An}$ additional argument for government intervention that is sometimes put forward is that large temporary shocks if fully passed on to producers may induce persistent (or permanent) effects on supply. In the case of tree crops, for example, replacement plantings may cease, leaving productive capacity reduced for a lengthy period of time and resulting in loss of market share.

${ }^{35}$ See Newbery and Stiglitz (1981) and Deaton (1992).

${ }^{36}$ But note that governments may also face liquidity constraints in international financial markets because of market imperfections or sovereign risk considerations.
} 
tion may be that individual agents lack the foresight or the means to engage in suitable savings strategies, or they lack the information to form reasonable expectations about the nature of commodity price shocks. Or alternatively, the assumption may be that income levels in many countries are so low that consumption spending by agricultural smallholders, for example, is close to subsistence levels with the result that the ability of producers to engage in precautionary saving is minimal.

Empirical evidence on savings behavior in developing countries is far from conclusive, but it does suggest that consumption smoothing takes place to a larger extent than traditionally assumed. At the macroeconomic level, one strand of literature has found that consumption behavior in some developing countries has often been close to what would be predicted on the basis of a standard permanent income model. ${ }^{37}$ The implication of these studies is that, in the face of fluctuations in income streams due to commodity price shocks and other disturbances, consumption paths in a number of developing countries have still been relatively smooth. As might be expected, however, this seems to be more the case for countries with higher income levels than for low-income countries in Africa and elsewhere.

The issue of whether developing countries have built up precautionary financial balances to act as a buffer or insurance policy in the face of changes in the underlying volatility of their export earnings has also been examined. ${ }^{38}$ According to the precautionary savings hypothesis, a consumer would build up a larger stock of financial assets the more volatile or unpredictable is his or her income. For a country as a whole, the volatility of export revenues creates an aggregate need for precautionary savings, which can only be accumulated through a more positive current account balance (savings minus investment). Looking at aggregate data for the current account for a large panel of developing countries, it has been found that the volatility of export earnings had a significant effect on the current account outcome, in conformity with the precautionary savings hypothesis. These results suggest that a considerable number of developing countries do indeed attempt to build up precautionary savings balances when they perceive an increase in the volatility of their export earnings. Note that, since the current account is the result of decisions by both private agents and the government sector, these test results apply to the aggre-

\footnotetext{
${ }^{37}$ See Ostry and Reinhart (1992) and Ghosh and Ostry (1993).

${ }^{38}$ See Ghosh and Ostry (1994).
}

gate behavior of the private and public sectors toward the volatility of export revenues.

At the microeconomic level, although the availability of data seriously limits the number of cases that can be studied, the evidence that agents react to commodity price instability in a manner consistent with theory is perhaps even more suggestive. This is because microeconomic survey data provide a better description of individual saving behavior than aggregate macroeconomic data. It has been found that rice farmers in Thailand, for example, smooth their consumption quite successfully both within and between harvest years. ${ }^{39}$ Evidence from Ghana further suggests that smallholders are capable of making sensible intertemporal choices between consumption and savings. ${ }^{40}$ Also, an analysis of the coffee boom in Kenya of 1976-79 found that as much as 60 percent of boom income went into private savings; farmers were aware that the boom was due to frost damage in Brazil and that their income gains were largely of a windfall nature. In contrast, it was estimated that the Kenyan government increased its spending by more than the increase in revenue generated by the coffee boom. ${ }^{41}$ At a minimum, the evidence at both the macroeconomic and microeconomic levels suggests that governments may be well advised to reassess their intervention strategies and the responsibility they assume for managing commodity price risk at the country level.

All in all, while in principle a case can be made for a government role to help smooth the incomes of private commodity producers because of financial market imperfections and information problems, there is empirical evidence to support the view that the private sector often tends to find ways of smoothing consumption in the face of commodity price shocks. Moreover, the experience with commodity price booms indicates that governments can find it difficult to manage properly the proceeds of temporary revenue windfalls. Thus, to the extent feasible, it seems advisable to adopt the policy of not interfering with price signals and using other means to deal with the side effects of price shocks. For example, the effects of commodity price fluctuations on low-income producers could be better addressed by resorting to social safety net measures.

\section{Intervention Strategies}

In part for the reasons discussed above, many governments in commodity-producing countries

\footnotetext{
${ }^{39}$ See Paxson (1992).

${ }^{40}$ See Ingham (1973).

${ }^{41}$ See Bevan, Collier, and Gunning (1989). Cuddington (1989) examines the fiscal difficulties experienced by Kenya, Nigeria, and Jamaica associated with commodity export booms.
} 
have chosen to assume a role in attempting to deal with the effects of fluctuations in international commodity prices on the domestic economy. In some metal- or mineral-exporting countries, the mining and refining companies are often partially or wholly owned by the state, which in addition to returns from holding equity may also levy export and income taxes. In countries exporting primary agricultural commodities, many governments levy significant export taxes that take on various forms (specific, ad valorem, adjustable levies) so that commodity price fluctuations may generate revenue instability. In other cases, state intervention takes the form of operating parastatal marketing boards. These boards typically set producer prices considerably below international prices and do not change them for lengthy periods of time in response to changes or trends in international prices. These kinds of arrangements tend to stabilize (at a lower level) the incomes of private agents while the fluctuations in international commodity prices are transmitted directly to the general budget via export taxes and/or the operating surplus of the parastatal marketing board. In some cases, however, the impact of commodity price fluctuations impinges in the first instance on the incomes of commodity-producing agents in the economy, and only indirectly on the fiscal position. ${ }^{42}$

The institutional structure can thus have an important influence in determining the aggregate impact on the economy of changes in international commodity prices and how macroeconomic stabilization and adjustment are effected. The nature of the intervention performed by these institutions has been varied, but the most often-used strategies are outlined below.

\section{Stabilization Funds}

Stabilization funds have been designed to deal with the impact of commodity price volatility on government revenues, especially in countries with a heavy dependence on metals and minerals. These funds act as a buffer for government expenditures and financing and have at least two appealing features. First, they impose a rule on governments, designed to use resources optimally from a longterm perspective, even if the effective planning horizon of the government is much shorter. The rule should lessen the risk that governments may be tempted to increase spending excessively during

\footnotetext{
${ }^{42}$ In Kenya, for example, export taxes are relatively minor and booms and slumps in world coffee and tea prices are reflected to a large extent in domestic producer prices; the government's budgetary position is largely affected by how private agents react in terms of consumption and investment decisions. These indirect effects can, nevertheless, be substantial.
}

temporary booms. And second, they constitute an institutional device by which governments can even out their expenditure, given that countries, as well as individuals, may be limited in their ability to smooth spending by imperfect access to international financial markets.

One scheme of this type has been put in place in Papua New Guinea whereby government revenues from mining are placed in the Mineral Resource Stabilization Fund (MRSF) whose assets, after accounting for drawdowns by the Government, are interest-bearing securities and deposits with the Bank of Papua New Guinea, the counterpart of which consists mainly of foreign deposits and securities. The Copper Stabilization Fund in Chile is another example of a formal institutional structure intended to save at least part of the gains realized by state-owned mining considered likely to be temporary, for use when copper prices drop.

The implementation of such schemes, however, is not without difficulties. One major problem is to set an appropriate benchmark price in order to determine at what rate disbursements should be made from the fund. For the MRSF in Papua New Guinea, for example, mining revenue projections were made over a five-year planning horizon based on price and output forecasts. In practice, year-toyear revisions in the rolling horizon revenue forecasts led to considerable variations in the government drawdowns recommended by the MRSF each year. ${ }^{43}$

\section{Agricultural Boards}

The other principal type of institutional structure for government intervention has been the stateowned agricultural board or fund. These are usually charged with a domestic price stabilization function, the transfer of explicit export taxes to central government, and a role in determining the extent to which operating surpluses are channeled into a formal stabilization fund or are transferred directly to central government (or to other uses). In Côte d'Ivoire, for example, the first objective was achieved by declaring a fixed producer price in nominal terms for coffee and cocoa. The board was able to stabilize producer prices (and thus producers' income) until international prices began dropping in 1986, which exerted increasing pressure on the organization's financial position. In 1989, the Government suspended the explicit export taxes, but even so was obliged to cut producer prices in half in 1990 in an attempt to limit

\footnotetext{
${ }^{43}$ See Claessens and Coleman (1991), who found that the variation in government drawdowns over the $1980-88$ period was only modestly lower than that of government mining revenue accruals.
} 
the operational deficit of the parastatal. During much of the period prior to 1986, fluctuations in international prices showed up primarily in the revenues of general government via the operating surpluses of the board. At times, particularly during the extraordinary beverages boom of $1975-78$ and the smaller boom in the mid-1980s, these revenues became very large and were principally used to finance spending on urban infrastructure and other development projects.

While similar schemes operated elsewhere in Africa, some other countries operated agricultural stabilization schemes quite differently. Papua New Guinea, for example, had schemes for coffee, cocoa, copra, and palm oil that used a ten-year moving average of inflation-adjusted commodity prices as the basis for paying bounties and mounting levies on actual free-on-board prices. As international prices declined in the mid- to late 1980 s, however, many of these programs experienced difficulties as drawdowns began to exhaust the funds.

The experience with stabilization schemes raises a number of issues about their desirability. First, stabilization schemes that transfer most of the effects of commodity price fluctuations to government may in fact be prone to exacerbating a country's fiscal management problems. ${ }^{44}$ For some countries the exercise of sufficient control over government expenditure is likely to pose serious difficulties, and there is some evidence to suggest that government responses to revenue gains and losses from commodity price fluctuations are asymmetric. 45 That is, it has proved much easier to adjust public expenditures upwards in boom periods than to adjust them downwards in slump periods. This reinforces the point made earlier that it may well be advisable for governments to share more of the commodity price risk with the private sector, particularly if reforms can also be undertaken to remove certain impediments (such as strict capital controls) that hinder the private sector's ability to handle fluctuations in commodity incomes. ${ }^{46}$

The situation may be further complicated by the fact that, to achieve a significant amount of income smoothing, it may be necessary for a fund to hold a relatively high level of foreign reserves or be in a position to borrow not insubstantial funds from international capital markets for stabilization purposes during downturns in commodity prices. The need for a relatively high level of foreign reserves (on average) arises from the fact that temporary

\footnotetext{
${ }^{44}$ See Cuddington (1989).

${ }^{45}$ See Deaton (1992).

${ }^{46}$ This does not mean that the agricultural sector should not be taxed; rather it means that the form of taxation needs to be reformulated.
}

commodity price shocks show considerable persistence and revert relatively slowly to trend. Moreover, holding such levels of foreign reserves will have a high opportunity cost as the rate of return on investment in most capital-short developing countries will be considered to exceed the rate of interest paid on foreign reserve holdings. This factor and the political pressures that may arise make such a reserves management strategy difficult to implement. In addition, during boom periods it may prove more difficult to enforce discipline on following appropriate project selection criteria, with the result that low-quality projects may be undertaken. Regarding international borrowing, many developing countries do not enjoy a credit rating that would enable them to obtain significant resources from private sources. Moreover, even for countries with some degree of access to international financial markets, financing may be more difficult to obtain, and more expensive, at times when commodity export prices fall, as this would create a less favorable outlook for the balance of payments.

Second, even if improvements to the institutional framework for stabilization schemes were to be implemented, they are still vulnerable to the difficulty of ascertaining ex ante the appropriate price level around which incomes should be stabilized. This requires an evaluation of the temporariness of price shocks and whether and how the underlying trend is changing. In particular, the difficulties that many stabilization schemes experienced from the mid-1980s onward may be traced to a failure to take into account the downward trend in commodity prices. Forecasting the future path of commodity prices is a notoriously difficult exercise, but the analysis presented earlier in this paper suggests that it might be possible to improve the working of stabilization schemes by paying greater attention to how particular commodity prices are evolving over time. The analysis of the beverages price index, for example, indicated that quite a large percentage of the shocks over recent years have been of a secular, persistent nature requiring adjustment in exporting countries. Temporary shocks do occur in the beverages markets, and when they occur they appear as price spikes generally associated with events such as the Brazilian frost in 1975 that led to a temporary boom in coffee prices. Thus, it makes little sense to put in place a domestic price stabilization scheme that does not take account of such factors and tries to stabilize prices around a constant mean in nominal or real terms. What might make more sense for designers of such schemes is to make estimates of the recent trend for the commodity price in question (which should be updated continuously), set up an intervention band based on the evolving properties of the price series, and 
intervene only when shocks push prices outside the band.

\section{International Commodity Agreements}

As volatility in international commodity prices affects the economies of all primary product exporters, there is an obvious basis for the idea of cooperative commodity agreements of some kind with the aim of attempting to achieve greater stability in international commodity prices. There may also be similar interest in importing countries, but it is likely to be less acute as their import structures generally tend to be much more diversified. Experience with ICAs has not in general shown them to have been successful.

Two aspects of ICAs should be differentiated. First, ICAs may attempt to increase the mean price of a commodity by restricting its supply by some method. And second, ICAs may simply limit price variability, for example, by recourse to buffer stocks. The first aspect is not considered favorably by importing countries and has been a source of contention, while the second one is perhaps less controversial. However, it is hard to pin down how much price stability is desirable; presumably, some degree of price flexibility must be allowed so that prices can provide the necessary signaling function for producers and consumers alike. More importantly, an ICA (or a producer-only scheme) runs the risk of trying to stabilize prices around the "wrong" (non-market-clearing) price, which can quickly lead to financial nonviability, the same problem discussed in the case of agricultural boards above, or to the collapse of output-sharing arrangements. On both political and economic grounds the prospects for ICAs playing a role in addressing the issues raised by recent international commodity price behavior appear somewhat dim.

\section{External Compensatory Finance}

Another means of trying to smooth out the effects of negative, temporary commodity price shocks for credit-rationed developing countries has been external compensatory finance from the IMF under the compensatory financing facility (CFF) and subsequently the compensatory and contingency financing facility (CCFF) and from the European Community under the STABEX scheme. ${ }^{47}$ The IMF's CCFF is designed to work

${ }^{47}$ It should be noted that such compensatory finance is a loan or a grant to the monetary authority or government of the country concerned. It need not, therefore, necessarily find its way to those who may be most directly affected by an export shortfall. best when temporary price shocks hit export earnings over a short period (the so-called "shortfall year"); then the destabilizing impact of the temporary shock can be offset in part by drawing under the facility, subject to early identification of the shortfall, access limits, and an appropriate policy response. In a similar vein, the contingency element of the CCFF is designed through a mix of financing and adjustment to help protect the programs of member countries being supported by IMF resources from being thrown off course by unanticipated shocks to key exogenous variables, such as commodity prices. Clearly, the design of policy responses and the form of IMF assistance to member countries must take into account the nature of the commodity price shock, namely whether it can be expected to be a short-lived, temporary shock or one that is likely to be longer lasting.

\section{Market-Related Instruments}

In addition to the possibility of reacting ex post to commodity price changes, it is possible for countries to trade away much of the commodity price risk, and the accompanying macroeconomic disturbances, by using financial securities such as futures and options. Producer countries can then limit their exposure to unanticipated price changes while investors in other countries assume it. In this way, risk is shifted internationally. But financial transactions of this sort at best insulate the economy from the problem of uncertainty, and at a cost. They do not avoid the effects of anticipated temporary or secular declines in prices.

The rise in short-run volatility of commodity prices since the early 1970 s has increased the attractiveness of hedging instruments. In addition to well-developed futures and options markets with short-dated instruments for commodities that account for a significant part of total commodity trade, financial innovation has led to developments in other instruments (commodity swaps, commodity options, commodity-linked bonds, forwards) that have increased the scope for hedging commodity risk. Such financial instruments have the advantage over other means of trying to handle risk in that they transfer much of the risk to parties outside the country concerned. Nevertheless, establishing a coherent hedging strategy is not a straightforward proposition and the use by developing countries of futures and derivative markets has only increased relatively slowly. It was for these reasons that both the World Bank and the United Nations Conference on Trade and Development created technical assistance programs focused on increasing awareness of external 
exposure in developing countries and providing assistance in risk management implementation. ${ }^{48}$

Here again it is necessary to take account of the institutional, marketing, and financial framework as it affects commodity price risk and who bears it. In countries where exporters face much of the commodity price risk, exchange controls may well rule out commodity hedging by the private sector and thus preclude optimal borrowing and lending behavior; changing this state of affairs may well help in reducing uncertainty and smoothing export earnings. ${ }^{49}$ Physical and price regulation of commodity exports constitutes an additional barrier to private sector hedging. In other cases, marketing institutions, marketing boards, or private exporters may act as simple intermediaries buying from small producers and arranging sales and shipments abroad. Some advance payments to producers may be made, but final settlement may await the end of the crop year; the intermediaries may have little incentive to hedge so that most of the commodity price risk is transferred to the small producer who is least able to protect himself. By marketing reform and amending marketing regulations it may be possible to reapportion the price risk and encourage those who are better placed to hedge to do so through the use of short-dated instruments.

Using exchange-traded futures contracts and options purchases can allow countries to offset some of the exposure to risk due to price volatility at the higher frequencies. Maturities tend to be limited to one to two years and market thinness can become a problem for the longer-dated maturities. There are also the costs of hedging in the form of brokerage fees and the need for agents to fulfill margin requirements (and prospective margin calls) or pay options premia in order to gain access to the market. Creditworthiness considerations may, however, make it considerably more difficult for developing countries to access other financial markets, particularly for nonstandard contracts and longer-dated instruments which would allow risk to be hedged more fully over time. Forward, swap, and option sales contracts all require consideration of the counterparty's creditworthiness, and as the length of a contract and the period of potential price movement extends out over time, the greater the risk that an intermediary in over-the-counter (OTC) markets assumes. In particular, sovereign risk for contracts with private agents and govern-

\footnotetext{
${ }^{48}$ Among countries assisted by the World Bank have been Chile, Colombia, Costa Rica, Indonesia, Papua New Guinea, Poland, Tunisia, and Uganda.

${ }^{49}$ In Colombia, for example, use of market-based risk management instruments by the private sector was banned until 1992.
}

ments in developing countries constitutes a serious obstacle to greater use of OTC markets. Overcoming high levels of sovereign risk by such means as collateralization and guarantee mechanisms is being investigated by OTC intermediaries and international organizations. ${ }^{50}$

\section{Government Policies for the Longer Term}

The previous sub-sections have dealt with policies aimed at mitigating the impact of international commodity price variability. But commodityexporting countries have also faced a downward trend in real prices. The earlier analysis suggests that it would be unwise to base policies on the assumption that the weakness in real commodity prices will be quickly overcome. A stronger economic recovery (and better growth performance over the medium term) in the industrial countries would certainly help, as would continuing high rates of growth in the newly industrialized countries. Some supply-side factors may ease over time (e.g., recent shocks to metals markets from the former Soviet Union), but other factors (e.g., structural change in exporting countries and productivity gains due to technical progress) seem unlikely to be reversed. If such is the case, those countries most seriously affected by permanent or highly persistent commodity price shocks must face the necessity of adjusting to the shocks and orienting their macroeconomic and structural policies toward this end.

Therefore, the secular decline in commodity prices poses the question of what-if any-are the appropriate structural policies for exporting countries, in particular those concerning resource reallocation away from primary products and those involving the type of international trade regime to be adopted. This was, in fact, a common motivation for policy initiatives in developing countries, particularly in Latin America, during the 1960s. Partially on the basis of the Prebisch-Singer hypothesis, a large number of Latin American countries pursued import-substitution strategies that aimed at reallocating resources away from primary product production and into heavy industry and manufactures directed to the domestic market. But these policies ended, in most cases, in failure as investments were undertaken in activities where countries did not enjoy comparative advantage, and the lack of competition generated stagnation and technical backwardness. As a result, many

\footnotetext{
${ }^{50}$ The International Finance Corporation (IFC), for example, has recently acted as a guarantor in several commodity swaps for companies in developing countries.
} 
Latin American countries have moved toward more outward-oriented trade regimes in the 1980s with apparent success.

The lessons from that experience are that while a negative terms of trade shock is certainly an adverse development from an exporting country's viewpoint, adding distortions to the domestic economy does not make things any better. For example, if domestic pricing policies insulate producers from the secular decline in international prices of commodities, there will be no incentives for producers to move toward more profitable activities (at world prices), eventually resulting in a bigger negative impact of the price decline. This is a risk for pricestabilization schemes that, in attempting to smooth out price fluctuations in the context of a secular decline, may get into the position of setting producer prices at levels that systematically exceed the international level that can be objectively expected to prevail.

This does not imply that there are no reasons for structural policies to target a reallocation of resources in light of developments in international commodity markets. It can be argued that an excessive reliance on a few export products can have a negative impact on the economy as a whole by increasing the "country risk" factor that is a consideration for international commercial lenders. This risk affects not just the exporting activity but the rest of the economy as well, since a balance of payments crisis would affect the repayment ability of any economic unit. This type of loss, however, should be compared with the effect of economic distortions that could result from efforts by the state to reallocate resources to other economic activities. In addition to standard economic arguments, the increasing body of evidence on crosscountry growth performance indicates that distortions to international trade and market-oriented resource allocation can have important deleterious effects on economic efficiency. 51

In addition, as policies and developments in one set of exporter countries have repercussions on others, an issue that can be raised is whether policy reforms aimed at enhancing growth prospects and efficiency have improved commodity export performance to the extent of being a major factor in the decline in commodity prices. ${ }^{52}$ The aggregate

\footnotetext{
${ }^{51}$ See, for example, Lee (1993) and Easterly (1993).

${ }^{52}$ In the extreme and static version of this argument, demand is price inelastic and the aggregate supply curve shifts to the right. The collective result is a reduction in overall commodity export earnings. However, while demand for a number of commodities has been estimated to be price inelastic in the short run, long-run price elasticities are higher.
}

supply of primary commodities has indeed been rising quite sharply in the 1980 s and this has quite clearly contributed to the downward movement in real commodity prices as evidenced by the econometric analysis presented earlier in this paper. However, it is not possible to isolate the extent to which structural reform programs and the removal of distortions in a number of primaryproducing countries have contributed to the decline in prices. What can be said is that the building up of distortions, such as punitive export taxation in earlier periods, led to lower exports and a higher price path for certain commodities than would otherwise have been the case, just as the removal of distortions may well have led to higher exports over time and a lower price path. It should, however, be stressed that in aggregate real export earnings from commodity exports have increased over time.

As data that were presented in Chart 3 show, the growth in the volume of commodity exports has been fairly uneven across regions. During the past decade, Asian economies and industrial countries have led the expansion, with African exports basically stagnant and Latin American performance somewhere in between. It has been observed that agricultural productivity growth in Africa has lagged behind that in Asia and Latin America and that this must constitute a significant factor in the comparatively weak performance of export volumes and the loss of market share in traditional export crops. ${ }^{53}$ But the implication is that, while for the economies with higher productivity growth the observed price declines may not imply losses in real revenue, economic difficulties would multiply for countries with poorer productivity performance.

But, once again, these developments do not imply that African or other commodity-exporting countries could make themselves better off by discouraging production of primary goods if that is where their comparative advantage lies. A relevant question, however, is whether individual producers of commodities take account of expected price evolution as a consequence of strategies and developments in competing countries. This is particularly relevant for such commodities as metals and tree crops where gestation periods for new investments may be extensive and the investments themselves long-lived. If it can be established that information failures are important, and to the extent that policymakers can achieve a better understanding of commodity price dynamics, policy action would be

${ }^{53}$ See Duncan (1993). 
warranted to help to provide better information and price signals. ${ }^{54}$

The experience of the fastest-growing developing countries shows that their export structures have evolved over time toward greater diversification (Tables 1 and 2). But these data show that a number of countries in Asia considerably increased primary product export volumes and market shares and widened the range of primary commodities they exported, while at the same time diversifying significantly into manufacturing exports. Latin American countries did not match this performance to the same extent, but a number of countries in the region enjoyed some success in terms of diversifying their export structures more toward manufactures. However, in terms of these yardsticks, countries in the African region fared poorly.

One important feature to be noted is that various types of diversification can take place simultaneously. In the agricultural sector, for example, farmers may respond to incentives to broaden their crop patterns to increase output of food crops to meet growing local demand. In many of the poorer countries, a significant proportion of the growth in such demand has in the past been met by imports. Also within the agricultural sector, diversification can consist of expansion or entry into less traditional activities (e.g., dairying, aquaculture, horticulture, fruit growing) on a commercial basis to satisfy urban demand or to be exported. And lastly, there is diversification into manufactures and their export.

\footnotetext{
${ }^{54}$ Unfortunately, as Deaton (1992) argues, the dynamics of adjustments in commodity markets and how longer-term expectations are formed are incompletely understood.
}

A recent review by the World Bank of the highperforming Asian economies provides some guidance as to how diversification was achieved. ${ }^{55}$ First, while agriculture's share of output and employment in these economies has declined significantly over time, growth in agricultural output and productivity was much higher than in other developing countries. ${ }^{56}$ The governments of these economies provided support to the agricultural sector through extension services, agricultural research, pilot schemes, significant investment in irrigation and rural infrastructure (roads, bridges, transportation, electricity, and water supplies), and nonpunitive crop taxation. Their experience indicates that establishing a dynamic agricultural sector constitutes an important phase in the diversification process; for lower-income countries the message is that failure to attach a sufficiently high priority to agriculture in favor of other sectors is likely to be counterproductive. Second, in addition to policies that generally provided a stable macroeconomic environment (including appropriate exchange rates), the highperforming Asian economies facilitated the more general process of diversification by public investment and institution building, by opening up their economies, by dismantling many of the regulatory barriers to resource reallocation, and by adopting policies or reforms that produced fewer distortions than in many other developing countries.

\footnotetext{
${ }^{55}$ This review of the performance of these economies provides a detailed assessment of the reasons and policies behind their growth. See The World Bank (1993).

56In fact, Young's (1993) estimates indicate that for the "four tigers," labor productivity in agriculture increased faster than in manufacturing. Labor productivity growth reflects both technical progress and fixed capital investment.
} 


\section{Conclusion}

T he analysis in this paper suggests that the marked decline in real commodity prices of the past decade should be regarded as being largely of a permanent nature that is not likely to be reversed. However, the results do not imply that commodity prices will continue declining at the same pace of the last few years. First, as noted in this paper, the permanent (or trend) component of commodity prices can (and does) change over time. Factors influencing the permanent component, such as agricultural and trade policies of both exporting and importing countries, may well exert a more positive influence in the future. For example, it is possible that the successful conclusion of the Uruguay Round bodes well for the prices of various cereals over the medium term. Second, cyclical fluctuations still play an important role in explaining the behavior of commodity prices. Rising commodity prices have accompanied almost all the major cyclical upturns in economic activity in the major industrial countries in the postwar period. The rebound in real commodity prices during the 1993:III-1994:I period by about 10 percent may be the most recent example of this pattern, as United States GDP growth accelerated to an annualized rate of 6.3 percent during the final quarter of 1993.

With regard to the determinants of real commodity prices, the paper has emphasized the important role supply conditions played during the 1980 s and, more recently, how developments in the former Soviet Union have influenced these markets. Explicit consideration of these factors represents a first step in broadening the "traditional" analysis of commodity price behavior, which tended to focus almost exclusively on demand conditions in the larger industrial countries. There remain, however, a number of key areas where the analysis of commodity prices could be extended. For instance, it is important to consider explicitly the role played by international commodity agreements, as it is often acknowledged that the breakdown of several such agreements has contributed appreciably to the weakness in commodity prices during the 1980s and 1990s. Similarly, it should prove useful to examine the direct and indirect effects of agricultural policies in the industrial countries on commodity prices. A better understanding of the underlying trends in technology that influence supply conditions is critical to the analysis. However, the complex and diverse nature of the factors that drive commodity markets, and the fact that some of these (technological changes, for instance) are hard to quantify, highlight the difficulties inherent in modeling and forecasting commodity prices.

Finally, irrespective of how the underlying trend in commodity prices evolves over the next few years, the analysis has also shown that price volatility remains high and that, a priori, there are no grounds to expect that such price uncertainty will appreciably diminish in the near future. This feature of commodity price behavior has increased the attractiveness of a variety of market-based risk management instruments. However, legal, financial, and technical barriers prevent many developing countries from taking advantage of promising hedging strategies. Specifically, lack of creditworthiness is a problem faced by many low-income, primary commodity-producing countries. To this end, it may be fruitful to examine to what extent international institutions can facilitate these countries' ability to deal with the problem of highly volatile export prices. 


\section{Appendix}

Table AI. Country Groupings for Charts 2 and 3

\begin{tabular}{|c|c|c|c|c|}
\hline \multirow[t]{2}{*}{$\begin{array}{l}\text { Developed Market } \\
\text { Economies }\end{array}$} & \multicolumn{4}{|c|}{ Developing Market Economies } \\
\hline & America & Africa & Middle East & South and Southeast Asia \\
\hline $\begin{array}{l}\text { Australia } \\
\text { Austria } \\
\text { Belgium } \\
\text { Canada } \\
\text { Denmark } \\
\text { Faeroe Islands } \\
\text { Finland } \\
\text { France } \\
\text { Germany } \\
\text { Gibraltar } \\
\text { Greece } \\
\text { Iceland } \\
\text { Ireland } \\
\text { Israel } \\
\text { Italy } \\
\text { Japan } \\
\text { Netherlands } \\
\text { New Zealand } \\
\text { Norway } \\
\text { Portugal } \\
\text { South Africa } \\
\text { Spain } \\
\text { Sweden } \\
\text { Switzerland } \\
\text { United Kingdom } \\
\text { United States }\end{array}$ & $\begin{array}{l}\text { Antigua and Barbuda } \\
\text { Argentina } \\
\text { Bahamas, The } \\
\text { Barbados } \\
\text { Belize } \\
\text { Bermuda } \\
\text { Bolivia } \\
\text { Brazil } \\
\text { Chile } \\
\text { Colombia } \\
\text { Costa Rica } \\
\text { Cuba } \\
\text { Dominica } \\
\text { Dominican Republic } \\
\text { Ecuador } \\
\text { El Salvador } \\
\text { Falkland Islands } \\
\text { French Guiana } \\
\text { Greenland } \\
\text { Grenada } \\
\text { Guadeloupe } \\
\text { Guatemala } \\
\text { Guyana } \\
\text { Haiti } \\
\text { Honduras } \\
\text { Jamaica } \\
\text { Martinique } \\
\text { Mexico } \\
\text { Montserrat } \\
\text { Netherlands Antilles } \\
\text { Nicaragua } \\
\text { Panama } \\
\text { Paraguay } \\
\text { Peru } \\
\text { St. Lucia } \\
\text { St. Kitts and Nevis } \\
\text { St. Vincent and the Grenadines } \\
\text { Suriname } \\
\text { Trinidad and Tobago } \\
\text { Uruguay } \\
\text { Venezuela }\end{array}$ & $\begin{array}{l}\text { Algeria } \\
\text { Angola } \\
\text { Benin } \\
\text { Botswana } \\
\text { Burkina Faso } \\
\text { Burundi } \\
\text { Cameroon } \\
\text { Cape Verde } \\
\text { Central African Republic } \\
\text { Chad } \\
\text { Comoros } \\
\text { Congo } \\
\text { Côte d'lvoire } \\
\text { Djibouti } \\
\text { Egypt } \\
\text { Equatorial Guinea } \\
\text { Ethiopia } \\
\text { Gabon } \\
\text { Gambia, The } \\
\text { Ghana } \\
\text { Guinea } \\
\text { Guinea-Bissau } \\
\text { Kenya } \\
\text { Lesotho } \\
\text { Liberia } \\
\text { Libya } \\
\text { Madagascar } \\
\text { Malawi } \\
\text { Mali } \\
\text { Mauritania } \\
\text { Mauritius } \\
\text { Morocco } \\
\text { Mozambique } \\
\text { Niger } \\
\text { Nigeria } \\
\text { Reunion } \\
\text { Rwanda } \\
\text { Sao Tome and Principe } \\
\text { Senegal } \\
\text { Seychelles } \\
\text { Sierra Leone } \\
\text { Somalia } \\
\text { Sudan } \\
\text { Swaziland } \\
\text { Togo } \\
\text { Tunisia } \\
\text { Uganda } \\
\text { Tanzania } \\
\text { Zaïre } \\
\text { Zambia } \\
\text { Zimbabwe } \\
\end{array}$ & $\begin{array}{l}\text { Bahrain } \\
\text { Cyprus } \\
\text { Iran, I.R. of } \\
\text { Iraq } \\
\text { Jordan } \\
\text { Kuwait } \\
\text { Lebanon } \\
\text { Oman } \\
\text { Qatar } \\
\text { Saudi Arabia } \\
\text { Syrian Arab Republic } \\
\text { Turkey } \\
\text { United Arab Emirates } \\
\text { Yemen } \\
\text { Pakistan } \\
\text { Philippines } \\
\text { Singapore } \\
\text { Sri Lanka } \\
\text { Taiwan Prov. of China } \\
\text { Thailand }\end{array}$ & $\begin{array}{l}\text { Afghanistan, I.S. of } \\
\text { Bangladesh } \\
\text { Brunei } \\
\text { Cambodia } \\
\text { Hong Kong } \\
\text { India } \\
\text { Indonesia } \\
\text { Korea, Republic of } \\
\text { Lao People's Dem. Rep. } \\
\text { Macau } \\
\text { Malaysia } \\
\text { Maldives } \\
\text { Myanmar } \\
\text { Nepal }\end{array}$ \\
\hline
\end{tabular}

Source: UNCTAD, Handbook of International Trode and Development Stotistics (Geneva: UNCTAD, 1993) 
Table A2. Country Groupings for Chart 7.

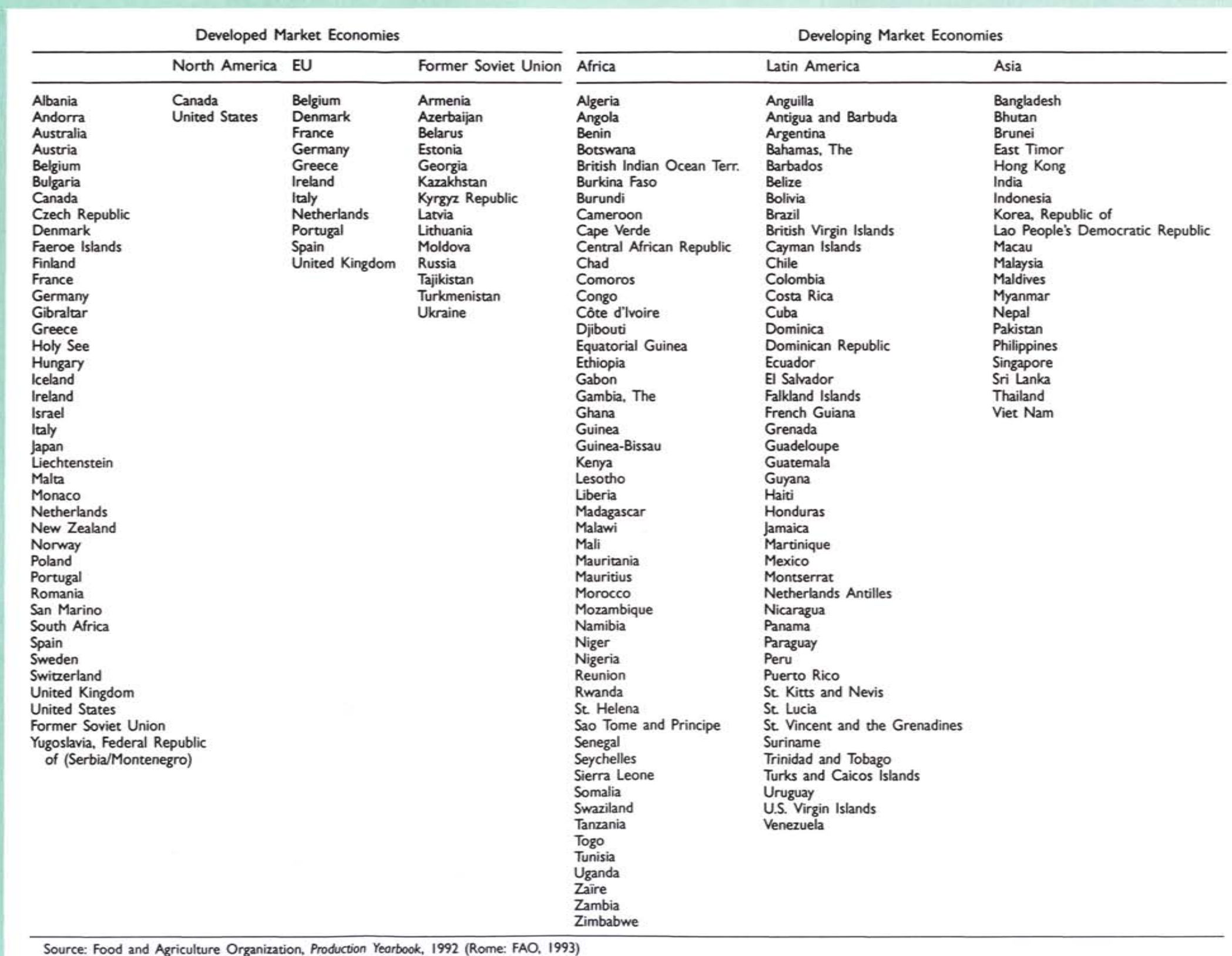




\section{References}

Adams, Charles, Paul R. Fenton, and Flemming Larsen, "Potential Output in Major Industrial Countries," in Staff Studies for the World Economic Outlook (Washington: International Monetary Fund, August 1987), pp. $1-38$.

Aizenman, Joshua, and Eduardo R. Borensztein, "Debt and Conditionality Under Endogenous Terms of Trade Adjustment," NBER Working Paper, No. 2582 (Cambridge, Massachusetts: National Bureau of Economic Research, December 1988), pp. 1-49.

Ardeni, Pier Giorgio, and Brian Wright, "PrebischSinger Hypothesis: A Reappraisal Independent of Stationarity Hypothesis," Economic Journal, Vol. 102 (July 1992), pp. 803-12.

Bevan, D.L., P. Collier, and J.W. Gunning, "Fiscal Response to a Temporary Trade Shock: The Aftermath of the Kenyan Coffee Boom," World Bank Economic Review, Vol. 3 (September 1989), pp. 359-78.

Borensztein, Eduardo, and Carmen M. Reinhart, "The Macroeconomic Determinants of Real Commodity Prices," Staff Papers, International Monetary Fund, Vol. 41 (June 1994), pp. 236-61.

Boughton, James M., "Commodity and Manufactures Prices in the Long Run," IMF Working Paper 91/47 (Washington: International Monetary Fund, May 1991).

Chu, Ke-Young, and Thomas K. Morrison, "The 1981-82 Recession and Non-Oil Primary Commodity Prices," Staff Papers, International Monetary Fund, Vol. 31 (March 1984), pp. 93-140.

"World Non-Oil Primary Commodity Markets: A Medium-Term Framework of Analysis," Staff Papers, International Monetary Fund, Vol. 33 (March 1986), pp. 139-84.

Claessens, Stijn, and Jonathan Coleman, "Hedging Commodity Price Risks in Papua New Guinea," Working Paper WPS 749 (Washington: World Bank, August 1991).

Cuddington, John T., "Commodity Export Booms in Developing Countries," World Bank Research Observer, Vol. 4 (July 1989), pp. 143-65.

"Long-Run Trends in 26 Primary Commodity Prices: A Disaggregated Look at the PrebischSinger Hypothesis," Journal of Development Economics, Vol. 39 (October 1992), pp. 207-27. , and Carlos M. Urzua, "Trends and Cycles in the Net Barter Terms of Trade: A New Approach," Economic Journal, Vol. 99 (June 1989), pp. 426-42.
Deaton, Angus S., "Commodity Prices, Stabilization, and Growth in Africa," Research Program in Development Studies, Discussion Paper 166, Princeton University (1992).

, and Guy Laroque, "On the Behaviour of Commodity Prices," Review of Economic Studies, Vel. 59 (1992), pp. 1-23.

Dobozi, Istvan, "The Centrally Planned Economies: Extravagant Consumers," Chap. 5 in World Metal Demand-Trends and Prospects ed. by John E. Tilton (Washington: Resources for the Future, 1990).

Dornbusch, Rudiger, "Policy and Performance Links Between LDC Debtors and Industrial Nations," Brookings Papers on Economic Activity, No. 2 (1985), pp. 303-56.

Duncan, R. C., "Market Diversification and Agricultural Export Prospects in Sub-Saharan Africa," in Policy Options for Agricultural Development in SubSaharan Africa, ed. by Nathan C. Russell and Christopher R. Dowswell (CASIN/SAA/Global 2000, 1993).

Easterly, William, "How Much Do Distortions Affect Growth?" Journal of Monetary Economics, Vol. 32 (November 1993).

Ghosh, Atish, and Jonathan Ostry, "Do Capital Flows Reflect Economic Fundamentals in Developing Countries?," IMF Working Paper 93/34, (Washington: International Monetary Fund, 1993).

"Export Instability and the External Balance in Developing Countries," Staff Papers, International Monetary Fund, Vol. 41 (June 1994), pp. 214-35.

Goldin, Ian, and Odin Knudsen, Agricultural Trade Liberalization: Implications for Developing Countries (Paris: OECD, 1990).

Grilli, Enzo R., and Maw Chang Yang, "Primary Commodity Prices, Manufactured Goods Prices, and the Terms of Trade of Developing Countries: What the Long Run Shows," World Bank Economic Review, Vol. 2 (January 1988), pp. 1-47.

Ingham, Barbara M., "Ghana Cocoa Farmers-IncomeExpenditure Relationships," Journal of Development Studies, Vol. 9 (April 1973), pp. 365-77.

Lee, Jong-Wha, "International Trade, Distortions, and Long-Run Economic Growth," Staff Papers, International Monetary Fund, Vol. 40 (June 1993), pp. 299-328.

Maizels, Alfred, Commodities in Crisis: The Commodity Crises of the 1980s and the Political Economy of International Commodity Prices (Oxford: Clarendon Press, 1992). 
Meadows, Donella, and others, The Limits to Growth: A Report for the Club of Rome's Project on the Predicament of Mankind (New York: Universe Books, 1972).

Newbery, David, and Joseph Stiglitz, The Theory of Commodity Price Stabilization: A Study of the Economics of Risk (Oxford: Clarendon Press, 1981).

Ostry, Jonathan D., and Carmen M. Reinhart, "Private Saving and Terms of Trade Shocks: Evidence from Developing Countries," Staff Papers, International Monetary Fund, Vol. 39 (September 1992), pp. 495-517.

Paxson, Christian H., "Consumption and Income Seasonality in Thailand," Research Program in Development Studies, Discussion Paper No. 150 (Princeton, New Jersey: Woodrow Wilson School of Public and International Affairs, Princeton University, 1992).

Perron, Pierre, "The Great Crash, the Oil Price Shock and the Unit Root Hypothesis," Econometrica, Vol. 57 (November 1989), pp. 1361-401.

Prebisch, Raul, The Economic Development of Latin America and Its Principal Problems (New York: United Nations, 1950).

Radetzki, Marian, "Developing Countries: The New Growth Markets," Chap. 4 in World Metal Demand-Trends and Prospects, ed. by John E. Tilton (Washington: Resources for the Future, 1990).
Reinhart, Carmen M., "Fiscal Policy, the Real Exchange Rate, and Commodity Prices," Staff Papers, International Monetary Fund, Vol. 38 (September 1991), pp. 506-24.

and Peter Wickham, "Commodity Prices: Cyclical Weakness or Secular Decline?," Staff Papers, International Monetary Fund, Vol. 41 (June 1994), pp. 175-213.

Sapsford, David, "The Statistical Debate on the Net Barter Terms of Trade Between Primary Commodities and Manufactures: A Comment and Some Additional Evidence," Economic Journal, Vol. 95 (September 1985), pp. 781-88.

Singer, H.W., "The Distribution of Gains Between Investing and Borrowing Countries," American Economic Review, Vol. 40 (May 1950), pp. 473-85.

Tilton, John E., "The OECD Countries: Demand Trend Setters," Chap. 3 in World Metal Demand-Trends and Prospects, ed. by John E. Tilton (Washington: Resources for the Future, 1990).

World Bank, The East Asian Miracle: Economic Growth and Public Policy (New York: Oxford University Press, 1993).

Young, Alwyn, "The Tyranny of Numbers: Confronting the Statistical Realities of the East Asian Growth Experience," Sloan School of Management, Massachusetts Institute of Technology (Cambridge, Massachusetts: MIT, 1993). 


\section{Recent Occasional Papers of the International Monetary Fund}

112. The Behavior of Non-Oil Commodity Prices, by Eduardo Borensztein, Mohsin S. Khan, Carmen M. Reinhart, and Peter Wickam.

111. The Russian Federation in Transition: External Developments, by Benedicte Vibe Christensen. 1994.

110. Limiting Central Bank Credit to the Government: Theory and Practice, by Carlo Cottarelli. 1993.

109. The Path to Convertibility and Growth: The Tunisian Experience, by Saleh M. Nsouli, Sena Eken, Paul Duran, Gerwin Bell, and Zühtü Yücelik. 1993.

108. Recent Experiences with Surges in Capital Inflows, by Susan Schadler, Maria Carkovic, Adam Bennett, and Robert Kahn. 1993.

107. China at the Threshold of a Market Economy, by Michael W. Bell, Hoe Ee Khor, and Kalpana Kochhar with Jun Ma, Simon N'guiamba, and Rajiv Lall. 1993.

106. Economic Adjustment in Low-Income Countries: Experience Under the Enhanced Structural Adjustment Facility, by Susan Schadler, Franek Rozwadowski, Siddharth Tiwari, and David O. Robinson. 1993.

105. The Structure and Operation of the World Gold Market, by Gary O'Callaghan. 1993.

104. Price Liberalization in Russia: Behavior of Prices, Household Incomes, and Consumption During the First Year, by Vincent Koen and Steven Phillips. 1993.

103. Liberalization of the Capital Account: Experiences and Issues, by Donald J. Mathieson and Liliana Rojas-Suárez. 1993.

102. Financial Sector Reforms and Exchange Arrangements in Eastern Europe. Part I: Financial Markets and Intermediation, by Guillermo A. Calvo and Manmohan S. Kumar. Part II: Exchange Arrangements of Previously Centrally Planned Economies, by Eduardo Borensztein and Paul R. Masson. 1993.

101. Spain: Converging with the European Community, by Michel Galy, Gonzalo Pastor, and Thierry Pujol. 1993.

100. The Gambia: Economic Adjustment in a Small Open Economy, by Michael T. Hadjimichael, Thomas Rumbaugh, and Eric Verreydt. 1992.

99. Mexico: The Strategy to Achieve Sustained Economic Growth, edited by Claudio Loser and Eliot Kalter. 1992.

98. Albania: From Isolation Toward Reform, by Mario I. Blejer, Mauro Mecagni, Ratna Sahay, Richard Hides, Barry Johnston, Piroska Nagy, and Roy Pepper. 1992.

97. Rules and Discretion in International Economic Policy, by Manuel Guitián. 1992.

96. Policy Issues in the Evolving International Monetary System, by Morris Goldstein, Peter Isard, Paul R. Masson, and Mark P. Taylor. 1992.

95. The Fiscal Dimensions of Adjustment in Low-Income Countries, by Karim Nashashibi, Sanjeev Gupta, Claire Liuksila, Henri Lorie, and Walter Mahler. 1992.

94. Tax Harmonization in the European Community: Policy Issues and Analysis, edited by George Kopits. 1992.

93. Regional Trade Arrangements, by Augusto de la Torre and Margaret R. Kelly. 1992.

92. Stabilization and Structural Reform in the Czech and Slovak Federal Republic: First Stage, by Bijan B. Aghevli, Eduardo Borensztein, and Tessa van der Willigen. 1992.

91. Economic Policies for a New South Africa, edited by Desmond Lachman and Kenneth Bercuson with a staff team comprising Daudi Ballali, Robert Corker, Charalambos Christofides, and James Wein. 1992.

90. The Internationalization of Currencies: An Appraisal of the Japanese Yen, by George S. Tavlas and Yuzuru Ozeki. 1992.

89. The Romanian Economic Reform Program, by Dimitri G. Demekas and Mohsin S. Khan. 1991.

88. Value-Added Tax: Administrative and Policy Issues, edited by Alan A. Tait. 1991. 
87. Financial Assistance from Arab Countries and Arab Regional Institutions, by Pierre van den Boogaerde. 1991.

86. Ghana: Adjustment and Growth, 1983-91, by Ishan Kapur, Michael T. Hadjimichael, Paul Hilbers, Jerald Schiff, and Philippe Szymczak. 1991.

85. Thailand: Adjusting to Success-Current Policy Issues, by David Robinson, Yangho Byeon, and Ranjit Teja with Wanda Tseng. 1991.

84. Financial Liberalization, Money Demand, and Monetary Policy in Asian Countries, by Wanda Tseng and Robert Corker. 1991.

83. Economic Reform in Hungary Since 1968, by Anthony R. Boote and Janos Somogyi. 1991.

82. Characteristics of a Successful Exchange Rate System, by Jacob A. Frenkel, Morris Goldstein, and Paul R. Masson. 1991.

81. Currency Convertibility and the Transformation of Centrally Planned Economies, by Joshua E. Greene and Peter Isard. 1991.

80. Domestic Public Debt of Externally Indebted Countries, by Pablo E. Guidotti and Manmohan S. Kumar. 1991.

79. The Mongolian People's Republic: Toward a Market Economy, by Elizabeth Milne, John Leimone, Franek Rozwadowski, and Padej Sukachevin. 1991.

78. Exchange Rate Policy in Developing Countries: Some Analytical Issues, by Bijan B. Aghevli, Mohsin S. Khan, and Peter J. Montiel. 1991.

77. Determinants and Systemic Consequences of International Capital Flows, by Morris Goldstein, Donald J. Mathieson, David Folkerts-Landau, Timothy Lane, J. Saúl Lizondo, and Liliana RojasSuárez. 1991.

76. China: Economic Reform and Macroeconomic Management, by Mario Blejer, David Burton, Steven Dunaway, and Gyorgy Szapary. 1991.

75. German Unification: Economic Issues, edited by Leslie Lipschitz and Donogh McDonald. 1990.

74. The Impact of the European Community's Internal Market on the EFTA, by Richard K. Abrams, Peter K. Cornelius, Per L. Hedfors, and Gunnar Tersman. 1990.

73. The European Monetary System: Developments and Perspectives, by Horst Ungerer, Jouko J. Hauvonen, Augusto Lopez-Claros, and Thomas Mayer. 1990.

72. The Czech and Slovak Federal Republic: An Economy in Transition, by Jim Prust and an IMF Staff Team. 1990.

71. MULTIMOD Mark II: A Revised and Extended Model, by Paul Masson, Steven Symansky, and Guy Meredith. 1990.

70. The Conduct of Monetary Policy in the Major Industrial Countries: Instruments and Operating Procedures, by Dallas S. Batten, Michael P. Blackwell, In-Su Kim, Simon E. Nocera, and Yuzuru Ozeki. 1990.

69. International Comparisons of Government Expenditure Revisited: The Developing Countries, 1975-86, by Peter S. Heller and Jack Diamond. 1990.

68. Debt Reduction and Economic Activity, by Michael P. Dooley, David Folkerts-Landau, Richard D. Haas, Steven A. Symansky, and Ralph W. Tryon. 1990.

67. The Role of National Saving in the World Economy: Recent Trends and Prospects, by Bijan B. Aghevli, James M. Boughton, Peter J. Montiel, Delano Villanueva, and Geoffrey Woglom. 1990.

66. The European Monetary System in the Context of the Integration of European Financial Markets, by David Folkerts-Landau and Donald J. Mathieson. 1989.

65. Managing Financial Risks in Indebted Developing Countries, by Donald J. Mathieson, David FolkertsLandau, Timothy Lane, and Iqbal Zaidi. 1989.

64. The Federal Republic of Germany: Adjustment in a Surplus Country, by Leslie Lipschitz, Jeroen Kremers, Thomas Mayer, and Donogh McDonald. 1989.

Note: For information on the title and availability of Occasional Papers not listed, please consult the IMF Publications Catalog or contact IMF Publication Services. 